Article

\title{
The Selected Method and Tools for Performance Measurement in the Green Supply Chain-Survey Analysis in Poland
}

\author{
Blanka Tundys * (1) and Tomasz Wiśniewski \\ Faculty of Management and Economics of Services, University of Szczecin, 71-004 Szczecin, Poland; \\ tomasz.wisniewski@wzieu.pl \\ * Correspondence: blanka.tundys@wzieu.pl; Tel.: +48-504-026-556
}

Received: 8 January 2018; Accepted: 14 February 2018; Published: 21 February 2018

\begin{abstract}
The methods and tools for the performance measurement and evaluation of the green supply chain management are very important elements for the construction and function of this type of supply chain. The result is a presentation of the considerations underlying a very general model, which presents some selected tools, but no breakdown of individual industries. The considerations undertaken are important and have scientific added value as usually in practice, a very large number of tools are used to assess the supply chain, which are not always correlated or adapted to the specificity of the chain. It is worth pointing out which of the already used or completely new tools and methods will be most useful for assessing the green supply chain. The structure of the paper covers the theoretical and empirical. It includes an introduction, our goals and hypotheses, state of the art, methodology, empirical findings, and discussion. We present the definitional differences between green and sustainable supply chains and focus on the selection and identification of methods for the framework model for evaluating the green supply chain. In the next step, the theoretical and selected method and tools were compared to a survey of Poland. On the basis of the survey, we present the findings and discussions found in this area. The main methodology used includes a literature review, a survey analysis using a questionnaire and statistical tools. The survey was carried out in 2015 in sample organizations in Poland. The research results showed that organizations were aware of the environmental elements of measuring and assessing the supply chain from an environmental point of view, but their use depended on many factors: the area, size of the organization, or the industry. If certain boundary conditions are met and the organizations are aware of the essence of environmental aspects in the chain, then they are applying green measures to the supply chain. These findings provide a glimpse into the measurement system and show that organizations still have yet to understand the essence of green and sustainable performance measurement, the meaning of its application, and the benefits it brings. However, traditional measurement still plays a large role, so it is important to reflect on how to convince organizations to pay more attention to environmental aspects, while at the same time applying a green supply chain assessment model. These results are a framework in which to start building a green supply chain assessment model. The empirical research aimed to answer the question of whether theoretical and sustainable management tools have already played a role in perceiving and assessing the green supply chain.
\end{abstract}

Keywords: methods; tools; framework; measurement of green supply chain; survey analysis; green supply chain assessment model; performance measurement in the green supply chain

\section{Introduction}

In literature and in business practices, it is possible to find many tools and methods to assess and evaluate a supply chain. Their analysis, in different contexts, appears in scientific publications. From a 
scientific point of view, which at the same time shows the scientific value added, it is essential to find tools and methods that support the management of a green supply chain. The specificity of the chain shows the need for dedicated tools. In the literature, there can be found traditional tools, methods, and instruments, where improvements or adaptations can be applied to green supply chains.

The measurement of the chain can be made in different contexts. Measuring the greenness of a logistics system or a supply chain should be flexible, and allow for changing priorities resulting from chances to the industry or products. The relevance of the subject matter is related to general economic trends as well as the broad scientific interest in new research areas. Poland actively engages in the international process of creating sustainable development. From the mid-1990s, the main factor for emissions reduction was increasing efficiency in the use of resources and energy. However, emissions reduction does not cover all sectors. In the case of transport, emissions grew as a result of the strongly pro-automotive policy implemented by Poland. All sectors of the economy (particularly in areas such as energy and agriculture) should be mindful of environmental considerations. Education policy has an important role in this process as it has great potential to encourage more sustainable behavior by consumers [1]. Poland is still a country where the principles of sustainable development in some cases are treated as a cost and not a competitive advantage. Therefore, based on the literature, a survey questionnaire was developed to ascertain the state of progress and the degree of utilization of green measurements in organizations.

The purpose of this paper outside of the theoretical aspect was to confront theory with economic practice, to draw conclusions, and to indicate what could be done in the future to change the present state of knowledge and awareness, and the green rules and tools-dominating supply chain assessment and other aspects were only an additional element. The aim of this discussion was to present the methods and tools that could be used to build an assessment model of a green supply chain. The article presents a wide range, and an overview, of the tools used in the literature. There is an emphasis placed on the tools used to evaluate green supply chains. The analysis presents a review of the methods with an indication of their theoretical and practical character. The considerations presented by the authors are based on the critical analysis of the literature. They indicate the importance of the considerations and an indication that the measurement of supply chain performance has of importance from both a research and practical point of view [2,3]. The effects of the actions taken can be used by both practitioners and scientists to show the author's point of view, and are supported by empirical research. Furthermore, in the paper, a theoretical model is presented whose elements make up a system for evaluating a green supply chain. In the model's framework, selected areas were highlighted and detailed tools, instruments, and concepts related to the implementation and evaluation of a green supply chain were assessed. The research-derived objective was to show whether companies that declared the introduction of green/sustainable supply chain aspects had real knowledge of this fact, whether they had certificates or applied these principles in practice, and how they differed from companies that did not declare the introduction of a green/sustainable chain. We also looked at how the approach of large companies differed from medium-sized companies, additionally depending on their position in the supply chain. Moreover, on the basis of the empirical findings, we also indicated the level of implementation or plans related to this area, the green or sustainable rules, and using environmental performance measurement in the supply chain. The discussion looked at the analysis of selected green components and tools related to performance measurement in individual organizations and comparative analysis in this field. The objectives were to confront the theoretical approach with economic practice, thus making it possible to revise the basis for a green supply chain assessment model with a particular focus on performance measurement.

Based on the literature and the theoretical part of these considerations, we proposed the following hypotheses. $\mathrm{H}(1)$ : Applying environmental oriented measurement tools has a positive impact on the creation of a green supply chain. $\mathrm{H}(2 \mathrm{a})$ : Sustainable and environmental oriented measurement tools are more often chosen by large organizations; $\mathrm{H}(2 \mathrm{~b})$ : at the same time, the industry in which they 
operate does not play a significant role; $\mathrm{H}(3)$ : the size of the organization (the number of employees) has an influence on the role that these organizations play in creating the green supply chain.

The paper is further organized as follows. Next section summarizes relevant literature on green and sustainable supply chains. In this section, authors described tools, indicators and measurement instruments for the evaluation process in the sustainable and green supply chains. Section 3 presents field analysis, which is an introduction to the description of the empirical findings shown in the next section. This section presents a narrow range of results from surveys conducted among companies in Poland. Finally, Section 5 concludes the paper with a summary and some further issues.

\section{State of the Art}

To consider the methods and tools used in the evaluation of green supply chain, its conceptual scope must be presented. This, in the literature, has been known for almost 30 years. A review of literature in this field is presented, among others, by Malviya and Kant [4]. It is important to distinguish between the scope and the elements of a green and sustainable supply chain. This is presented below in a short summary of the characteristics of both concepts of the supply chain. The following discussion focuses on two types of chain, the measurement of which are extremely important due to the introduction of the principles of sustainable development: the green and sustainable supply chains. Undoubtedly, the two concepts are not clearly separate from each other and can be investigated from different perspectives, which shows some differences Since the early 2000s, academics as well as practitioners in the field of GSCM-green supply chain management and SSCM-sustainable supply chain management have conducted research covering a wide range of issues [5]. In the field of performance measurement, many studies have been developed, which are reflected in the work van Hoek [6], Hervani et al. [7], King and Lenox [8], Varsei et al. [9] and in the latest journals paper by Maestrini et al. [10]. Undoubtedly, in the consideration should be given to studies on identifying the performance measurement of the green supply chain as well as assessment models for this strategy. The study presented by Centobelli, Cerchione, Esposito [11] included interesting point of view in the area of the green supply chain. On the basis of the content analysis, they had shown the influence of green initiatives on different types of performance. It could be the basis for the future work and considerations. Environmental performance is of particular importance here, which should be considered as one of the most important elements in the development of the green supply chain assessment model.

\subsection{Green Supply Chain Management (GSCM)}

Definitions of a green supply chain can be divided and classified according to the extent of impact and areas of influence.

GSCM (Green Supply Chain Management) is defined as the integration of environmental thinking into supply-chain management including product design, material sourcing and selection, manufacturing processes, delivery of the final product to the consumers as well as end-of-life management of the product after its useful life [12]. This topic is an important point of consideration for the following authors: Beamon [13], which was among the first to focus on showing how designing of the green supply chain should be done; Davies, Hochman [14], indicate in a general way the processes of greening the supply chain; Rettab and Ben Brik [15] show examples of the functioning of the green supply chain, Zhu and Sarkis [16], who focus on inter-sectoral aspects and comparison of solutions in the Zaresie green supply chain maanggement; Gilbert [17], Hwa [18], Rao and Holt [19] and Vachon and Klassen [20], show the possibilities to improve competitiveness thanks to greening of the processes, Zsidisin [21], indicat the operational aspect of greening processes-green purchases, Skjoett-Larsen [22] focuses on the aspect of cooperation with logistics operators. Information systems and technologies, transportation, warehousing and logistics networks have been integral components of Supply Chain Management (SCM) at the current stage of economic development and the environmental trend factors such as environmental purchasing, manufacturing, $R \& D$, and distribution have emerged as new areas that should be considered when constructing and evaluating an SCM. 
To design a green supply chain also requires designing a system of operational and environmental performance measures to help identify green and non-green practices. It is inadequate to use a single performance measure (e.g., cost) as it ignores the interactions among important supply chain characteristics and organizational strategic goals (e.g., resources, output, and flexibility) of the supply chain $[13,23]$. Influence of greening the suppliers and green innovation on environmental performance is considered to be an element of competitive advantage by Chiou, Chan, Lettice, Chung [24].

By analyzing the latest literature on the subject, it should be pointed out that the directions of research in this field are increasingly related not only to creation, measurement, and evaluation, but also to the indication of risk. An important from the point of view of considerations taxonomy of green goals, practices, and technology related to the process approach of the supply chain was presented by Centobelli, Cerchione, Esposito [25]. Green supply chain initiatives are adopted to reduce costs, increase efficiency, customer satisfaction (both external and internal), increase market share, manage risk more effectively [26], and increase competitiveness [27]. Many studies have also been devoted to variables that impede the implementation of GSCM [28-30]. An analysis of these activities is necessary to be able to further develop issues related to the implementation of environmental principles in the framework of the chain [31-35]. In recent years, research on barriers to the creation of a GSCM has also been carried out by Rauer and Kaufmann [34], who analyzed external factors [30] in the context of 3PL (Third Party Logistics). The impact of green practices on chain performance based on a case study is studied by Azevedo, Carvalho, and Machado [36].

There is no doubt that further analysis of the GSCM is necessary [37-39]. Currently, authors focus more on the measurement and practical application of the GSCM principles. In the context of considerations, there is also important to indicate the most frequently used, on the basis of research, tools and instruments concerning the measurement of efficiency and the construction of the green supply chain assessment model. The success of the implementation of green rules into the supply chain practice depends on many critical factors and the relationships between them. A wide consideration on this subject is showed by Garg, Sharma, Goyal [40].

In the context of research and selected industries conducted by the authors, it should be noted that the topic of environmental problems in the food industry are described in the literature with the help of Multi-Criteria Decision Making and statistical approaches [41]. The food industry is of great interest to researchers in this field. The results of the research can be found in the works [42,43], there is similar interest in the production of clothing [44-46], as well as in the production of household articles [47,48], although the analysis of the literature indicates that most research in this area is devoted to the automotive industry [47,49-51].

Compared with conventional supply chain management, GSCM focuses mainly on implementing a green development strategy while managing the external environmental pressures as well as the internal impetus of corporate innovation [52]. Based on the latest literature, it is possible to say that the adoption of GSCM practices by organizations has led to increased operational and organizational performance [53]. Companies are increasingly being urged to play their part in taking action to avert long-term irreversible damage to our planet, and they are setting up environmental programs to incorporate green policy throughout various stages of their supply chain. GSCM aims to limit waste within production to save energy and lessen the effects of harmful materials on the environment [54]. Considerations regarding performance measurement in the green supply chain are also conducted in a broader approach by Paksoy, Bektaş and Özceylan [55].

\subsection{SSCM—Sustainable Supply Chain Management}

Most definitions of SSCM (Sustainable Supply Chain Management) include a consideration of environmental, economic, and social issues while improving the long-term economic performance of supply chains [23]. Taking these factors into account has led to the definition of a Sustainable Supply Chain Management (SSCM) [12] as "the strategic, transparent integration and achievement of an organization's social, environmental and economic goals in the systemic coordination of key 
inter-organizational business processes for improving the long-term economic performance of the individual and its supply chain". Supply-chain management is categorized into three main aspects: sustainable development; environmental, and social criteria, which must be met by the supply chain (business units) and the competitiveness of the chain, which will help to meet the needs of the customer $[54,56]$. SSCM integrates environmental thinking into supply-chain management including product design, material sourcing and selection, manufacturing processes, delivery of the final product to the consumer, and end-of-life management of the product (recycling, close loop). The main imperatives on implementing sustainable supply chains from a theoretical point of view are presented Figure 1. Figure 1 shows that the concept requires the integration of various levels and cooperation in many areas ranging from operational to strategic long-term activities, both intra-organizational and requiring the necessity to adapt to legislative actions at the governmental level.

Analysis of the literature on the subject indicates a lot of interest in the subject, both in the theoretical context and in its practical reflection. The comprehensive state of the art has been presented by Ansari and Kant [57]. The scope of literature research has also been presented by Beske and Seuring [58], Ahi and Searcy [59], Carter and Easton [60], Seuring and Müller [56], Rajeev et al. [61] and Chen, Kitsis, [62]. Modeling based on the literature of the subject has been presented by Dubey et al. [63] and Bendul [64], also by Wu, Santoso, Roan [65].

A practical approach to issues of enterprise performance including overall performance as well as social, environment and economic, has been pointed out in Hong et al. [66]. Frostenson considered the network connections [67]. The risk aspects have been covered by Song et al. [68]. The aim of the sustainable concepts is to minimize the negative green impact. In this case, companies should consider the environment as an opportunity upon which they can build a competitive advantage [69].

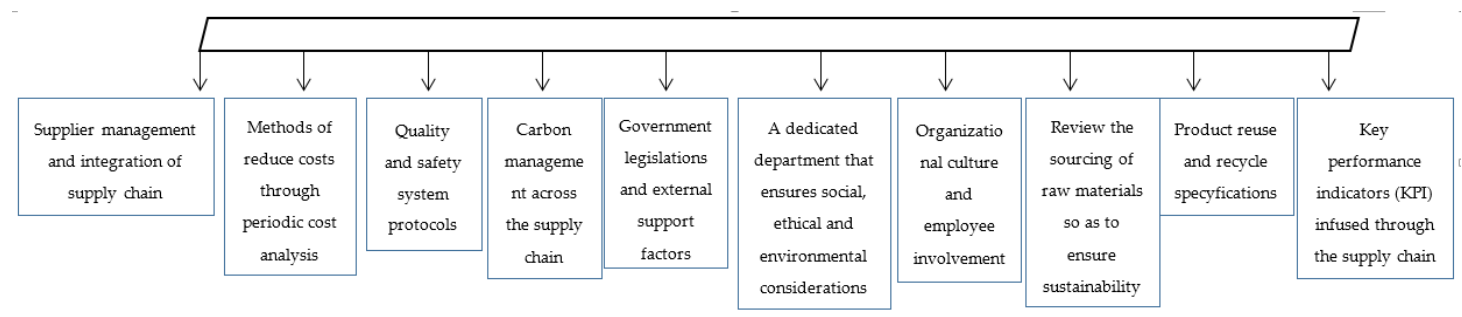

Figure 1. Imperatives of implementing Sustainable Supply Chain. Source: own elaboration based on [56].

In the above section, we characterized the concepts of a green and sustainable chain. By analyzing the literature [69] both concepts were shown and compared by looking for common elements and highlighting the differences between them.

\subsection{Performance Measurement and Indicators in the Green and Sustainable Supply Chain}

\subsubsection{Selected Tools}

In the evaluation of a supply chain, many instruments and concepts can be used. The more comprehensive the evaluation, the less the chance something is overlooked. However, to assess green or sustainable supply chains, a more versatile and universal evaluation tool should be created. The literature is rich in studies on tools for measuring the assessment of the green chain addition. A wide spectrum of this research area presented Chaudhary and Chanda [70]. It is also important that dedicated instruments and tools are selected in such a way as to simplify the reality and allow a model to be created with a selected universal set of tools. Instruments for the evaluation model should be identified in the following areas: management, economic, legal and administrative (organizational), as well as activities within the social sphere. For the SSCM, the most important and useful methods and tools embrace three aspects of sustainability: economic, social, and environmental. 
In most cases of evaluating an SSCM, it is best to use the tools connected to close-loop supply chains. In the case of the GSCM, the emphasis is on green processes, which include designing, planning, measuring, and evaluation. A summary of the tools used is presented in Table 1. The elements presented in Table 1 are a taxonomic approach. Selected elements based on the subject literature have been subjected to a pre-survey analysis. Based on the obtained results, a set of elements most often used to assess processes in the sustainable and Green supply chain was created. The authors do not divide green and sustainable initiatives at this point, as this division took place in subsequent stages of research.

Table 1. Tools, instruments, and indicators for the evaluation process in the sustainable and green supply chain-environmental perspective.

\begin{tabular}{|c|c|c|}
\hline Tools, Instruments & Activities & Others \\
\hline KPI (Key Performance Index) [71] & \multirow{2}{*}{$\begin{array}{l}\text { Carbon Assessments and } \\
\text { Footprinting [83] }\end{array}$} & \multirow{2}{*}{$\begin{array}{l}\text { EU Directives and Guidelines, Recommendations, } \\
\text { Accreditations, Certifications (ISO) [94] }\end{array}$} \\
\hline End of life Inventory Management [72] & & \\
\hline \multirow{2}{*}{$\begin{array}{l}\text { Packaging Assessments (Packaging } \\
\text { Environmental Assessment Tool-PEAT [73] }\end{array}$} & Green vendor selection [84] & \multirow{2}{*}{$\begin{array}{l}\text { Engaging with Suppliers on Sustainability } \\
\text { (TESS) [95] }\end{array}$} \\
\hline & Eco-performance measuring $[85,86]$ & \\
\hline Life Cycle Analysis (LCA) [74] & $\begin{array}{l}\text { Environmental rules of suppliers } \\
\text { selections [87] }\end{array}$ & $\begin{array}{l}\text { Executive opinion on environmental } \\
\text { regulation [96] }\end{array}$ \\
\hline Life Cycle Costing (LCC) [75] & Waste management [87] & \multirow{2}{*}{ Demand for eco-innovative products [97] } \\
\hline ESCOR $[76,77]$ & Remanufacturing [88] & \\
\hline $\begin{array}{l}\text { Environmentally Responsible Product } \\
\text { Assessment (ERPA) [78] }\end{array}$ & \multirow[t]{2}{*}{$\begin{array}{l}\text { Financial support for eco-innovation from } \\
\text { public programmers [89] }\end{array}$} & \multirow{2}{*}{$\begin{array}{l}\text { Seed and start-up venture capital for } \\
\text { eco-innovative firms (investment per } \\
1000 \text { GDP), [97] }\end{array}$} \\
\hline Material Flow Analysis(MFA) [79] & & \\
\hline $\begin{array}{l}\text { Environmental Quality Function Deployment } \\
\text { (EQFD) [80] }\end{array}$ & $\begin{array}{l}\text { Purity of recyclable materials } \\
\text { recovered [90] }\end{array}$ & $\begin{array}{l}\text { Ratio of eco-start-ups to incumbents in the } \\
\text { market [97] }\end{array}$ \\
\hline Sustainable Balanced scorecard [81] & Eco cooperation's form [91] & Emission from in/outbound logistics [97] \\
\hline \multirow[t]{4}{*}{ VSM-Value stream mapping [82] } & $\begin{array}{l}\text { Waste management costs (landfill } \\
\text { tariff, etc.) [92] }\end{array}$ & Emission from raw material sourcing, [97] \\
\hline & $\begin{array}{l}\text { Concentrations of hazardous materials in } \\
\text { products and by-products [93] }\end{array}$ & $\begin{array}{l}\text { 'Green Tax' as a percentage of government } \\
\text { budget [97] }\end{array}$ \\
\hline & & $\begin{array}{l}\text { Share of eco-innovative firms as a percentage of } \\
\text { all firms [97] }\end{array}$ \\
\hline & & Useful product operating life [97] \\
\hline \multicolumn{3}{|l|}{ Indicators (based on: $[7,71,97])$} \\
\hline \multirow{3}{*}{$\begin{array}{l}\% \text { of orders receives with eco-packing, } \\
\text { regulations, certifications, } \\
\text { green procurement,) }\end{array}$} & \multirow{3}{*}{$\begin{array}{l}\% \text { recyclable/reusable materials (volume } \\
\text { or weight) available at end of product life }\end{array}$} & Total energy consumed \\
\hline & & Total mass of products produced \\
\hline & & $\begin{array}{l}\text { Total material consumed (e.g., water, timber, } \\
\text { steel, etc.), }\end{array}$ \\
\hline$\%$ of returned products & $\begin{array}{l}\% \text { product volume or weight recovered } \\
\text { and re-used }\end{array}$ & Total toxic or hazardous materials used \\
\hline$\%$ of firms with EMAS or ISO 14001 & The ratio of wastes to all outputs & Total toxic or hazardous waste generated \\
\hline \multirow{2}{*}{$\begin{array}{l}\% \text { of firms with environmental } \\
\text { mission statements }\end{array}$} & \multirow{2}{*}{$\begin{array}{l}\% \text { recycled materials (weight or volume) } \\
\text { used as input to manufacturing }\end{array}$} & Direct material input(DMI), \\
\hline & & Physical trade balance(PTB), \\
\hline \multirow{2}{*}{$\begin{array}{l}\text { Solid waste emissions \% product (weight or } \\
\text { volume) disposed in landfills }\end{array}$} & \multirow{2}{*}{$\begin{array}{l}\% \text { product disposed or incinerated } \\
\text { Fraction of packaging or containers }\end{array}$} & Total domestic output(TDO), \\
\hline & & Domestic Material Consumption (DMC) \\
\hline \multirow{2}{*}{$\begin{array}{l}\text { Emission of greenhouse gases per unit of } \\
\text { GDP, reduce of greenhouse gases }\end{array}$} & \multirow{2}{*}{$\begin{array}{l}\text { Number of purchase of hybrids, electric } \\
\text { cars, flex-fuel vehicles }\end{array}$} & Domestic extraction used (DEU) \\
\hline & & Recycled Material Recovery rate (MRR) \\
\hline Time required for product recovery & $\begin{array}{l}\text { Average energy use per square foot of } \\
\text { office space }\end{array}$ & Core Return Rate (CRR) \\
\hline Material productivity of eco innovative firms & $\begin{array}{l}\text { Number of eco-investment, } \\
\text { eco-innovation, eco-patents }\end{array}$ & \\
\hline $\begin{array}{l}\text { Ratio of materials recycled to materials } \\
\text { potentially recyclable }\end{array}$ & $\begin{array}{l}\text { Average total life-cycle cost savings } \\
\text { associated with design improvements }\end{array}$ & \\
\hline Economic output per unit of material input & $\begin{array}{l}\text { Estimated annual risk of adverse effects in } \\
\text { humans and biota }\end{array}$ & \\
\hline \multirow[t]{3}{*}{$\begin{array}{l}\text { Purchase and operating cost incurred by } \\
\text { the consumer }\end{array}$} & $\begin{array}{l}\text { Average life-cycle cost incurred by } \\
\text { the manufacturer }\end{array}$ & \\
\hline & The amount of energy cost & \\
\hline & compliance cost, non-compliance cost & \\
\hline
\end{tabular}




\subsubsection{Environmental Performance Measurements in Supply Chain}

Classic measurements of the performance of the supply chain include customer satisfaction, service, time, responsiveness, cost, and quality. From the point of view of greening and creating new strategies for supply chains, fresh measurements should be developed, which can be added to the classic list or form the basis for a new point of view at the assessment of the chain. One of the first published studies to measure performance in the supply chain was by Beamon [13], among others. A performance measurement system was defined as "A performance measure, or a set of performance measures, is used to determine the efficiency and/or effectiveness of an existing system, or to compare competing alternative systems. Performance measures are also used to design proposed systems, by determining the values of the decision variables that yield the most desirable level(s) of performance". An environmental performance measurement system should generally lead to the ability to simultaneously satisfy cost, quality, and performance goals, reduce environmental impacts, and conserve valuable resources. A system of performance measures should also include quantitative and qualitative indicators. They should be both financial and non-financial. A measuring system for the environmental performance of a supply chain can use qualitative (e.g., management involvement, marketing and green image, green design, accidents or spills, lawsuits, quality awards, certification, CSR — corporate social responsibility, etc.) factors and quantitative (e.g., energy, waste, transportation, etc.) measures.

Manufacturing performance is usually assessed in terms of cost, quality, delivery, and flexibility, whereas environmental performance commonly measures the amounts of pollutants released into the air from industrial plants and hazardous substances transferred from and to other plants/markets that probably end-up as landfill that affects soil and water quality [98]. Researchers have suggested that in addition to the social costs and the direct cost of greening an organization, environmental performance measures should be able to measure the tangible and intangible outputs of a system as well as the partial outputs at different levels of the organization [7]. Based on the literature, quantitative and qualitative indicators for measuring the greening of the supply chain can be presented. A number of qualitative performance measures could be included: management involvement, marketing and green image, disposal methods, environmental policies and audits, a quality system (e.g., ISO 14000), accidents or spills, lawsuits, reward or certifications, training, environmental ranking performance, environmental, data collection systems, process innovation, product design for remanufacturing, supply redundancy, buying environmental friendly materials, technology, interaction with suppliers, transportation modes, packaging, stimulating recovery policy; and the quantitative pollution effect: solid waste, air emission, water waste, chemical waste (e.g., lead), energy used, thermal pollution; financial: recovery cost (+/-), market share gain (demand, stock price, and transport distance. The performance measurements and indicators for GSCM can be grouped within the context of sustainable development meaning through an economic perspective such as environmental cost, traditional supply chain cost, quality, flexibility, responsiveness; an environmental perspective including the level of process management, product features, recycling efficiency, environmental technology; and from a social perspective such as management commitment, customer satisfaction, and employee development. The selected measurement indicators were developed on the basis of El Saadany et al. [98], Kafa, Hani and El Mhamedi [99] Acquaye et al. [100], Mishra et al. [101] Balfaqih et al. [102], Lima-Junior and Carpinetti [103], Maestrini et al. [10], and Varsei et al. [9]. The presented measures are only part of a larger whole. They point to areas of interest in the areas and directions for the building of the assessment model. In the next step and in future works, other methods, components and tools for the measurement of the green supply chain and its efficiency will be indicated. Zhu et al. [104] argued that the lack of a clear relationship between GSCM practices and performance improvements was an obstacle for manufacturers seeking to justify GSCM implementation. Referring to Golicic [105], it can be stated that despite the growing number of studies on the economic links and on the level of sustainable development and environmental aspects, the results of the research have so far failed to find the answers that would be most beneficial to an organization. In recent years, the relationships 
between GSCM practices and performance have been studied by many researchers, for example, Laari et al. [106], Dubey [107], and Schrettle [108]. Many studies have demonstrated that GSCM can improve environmental performance. Das [109] pointed to the broadly understood aspects of performance measurement in terms of sustainability and competitiveness. Performance measures may also be considered from the perspective of a balanced scorecard (BSC): financial, internal process, customer learning, and growth perspective [7].

\subsubsection{Selected Measurement Instruments of the Green Supply Chain}

This part of the discussion aimed to select the dedicated tools for evaluating the green supply chain as it is important to identify the most important aspects needed to build the system. (Figure 2).

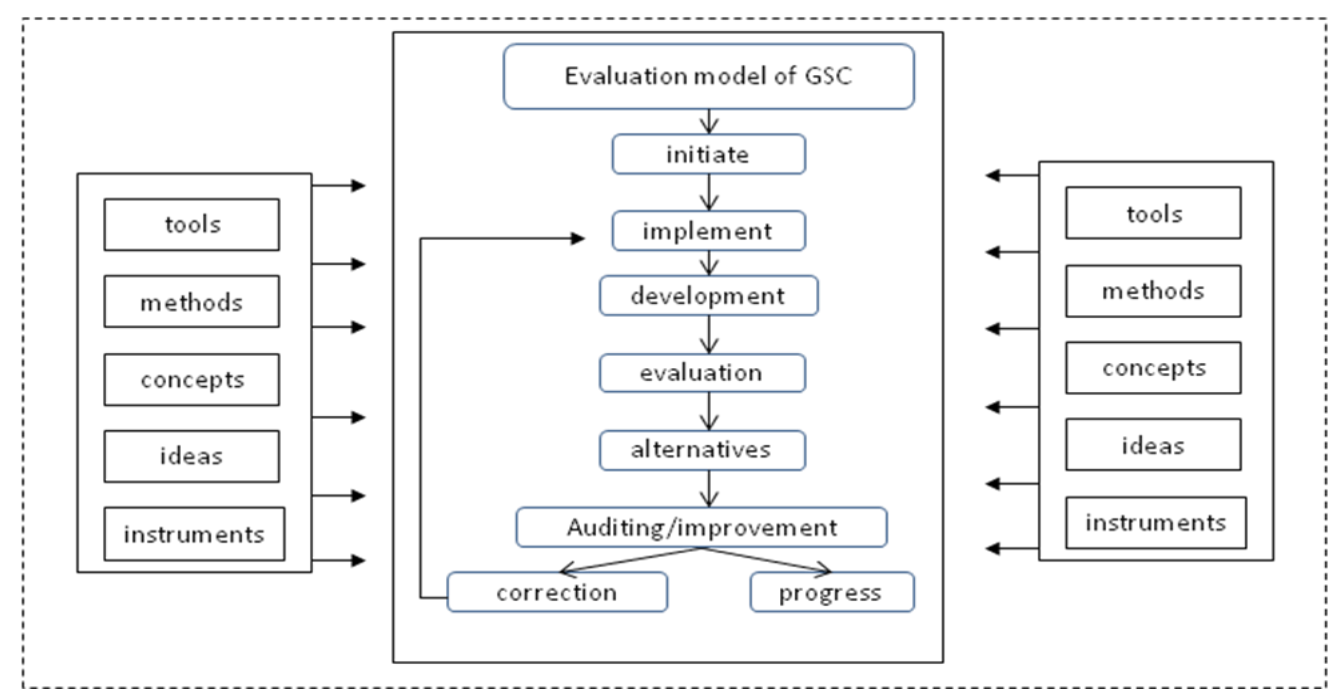

Figure 2. The main research steps of an evaluation model of a green supply chain.

As shown in Figure 2, at all stages of the model construction should various kinds of methods, concepts, ideas and instruments and attachments for be made available for implementing new ideas? This scheme (Figure 2) helps in the decision-making, modeling, and tool selection process required when it comes to constructing a green supply chain. By interpreting the above drawing, it should be pointed out that by starting the construction of the framework of the green supply chain model, all of the analysis should be performed (at every stage) in accordance with the above algorithm. It will allow avoiding errors or mismatching of elements to the assumptions of the assessment model.

The base model for the evaluation system of a green supply chain is presented in Figure 3. It was created on the basis of the literature covering the key areas of measurement: (1) green design, operations (and here procurement, production, manufacturing, distribution and reverse logistics), as well as—not included in the figure, but still very important-the processes accompanying each logistics activity, namely: transportation, warehousing and packaging; (2) the part of the scheme (Figure 3) presenting a selection of the components that should be taken into account when building the base model, and focuses on the processes and activities performed in specific areas; and (3) the last part of the model indicates areas of interest within the individual processes. There is a crossover in the processes as most of them can be used in each part of the process. A description of the individual elements can be found in Figure 4. 
Assesmentsystem of green supply chain - framework model

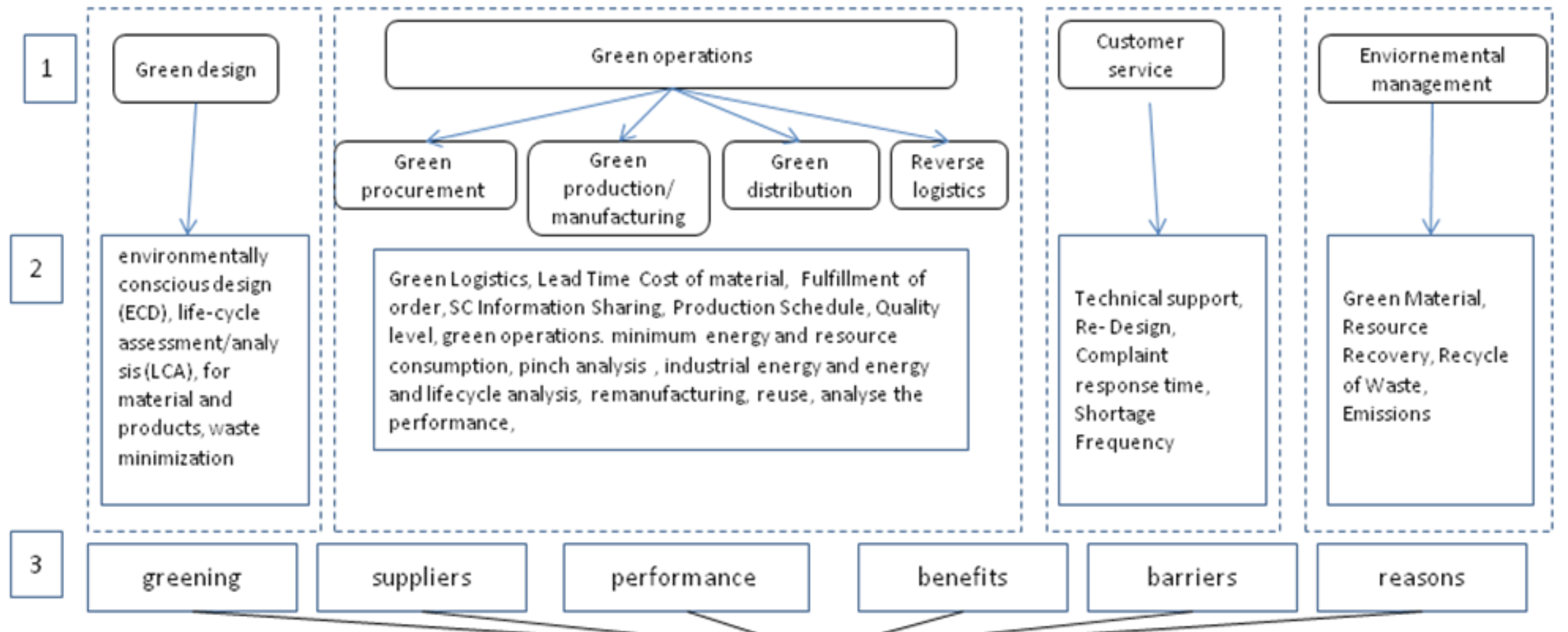

Methods/tools/instruments/conceptes/ideas

Figure 3. Framework model of a green supply chain. 


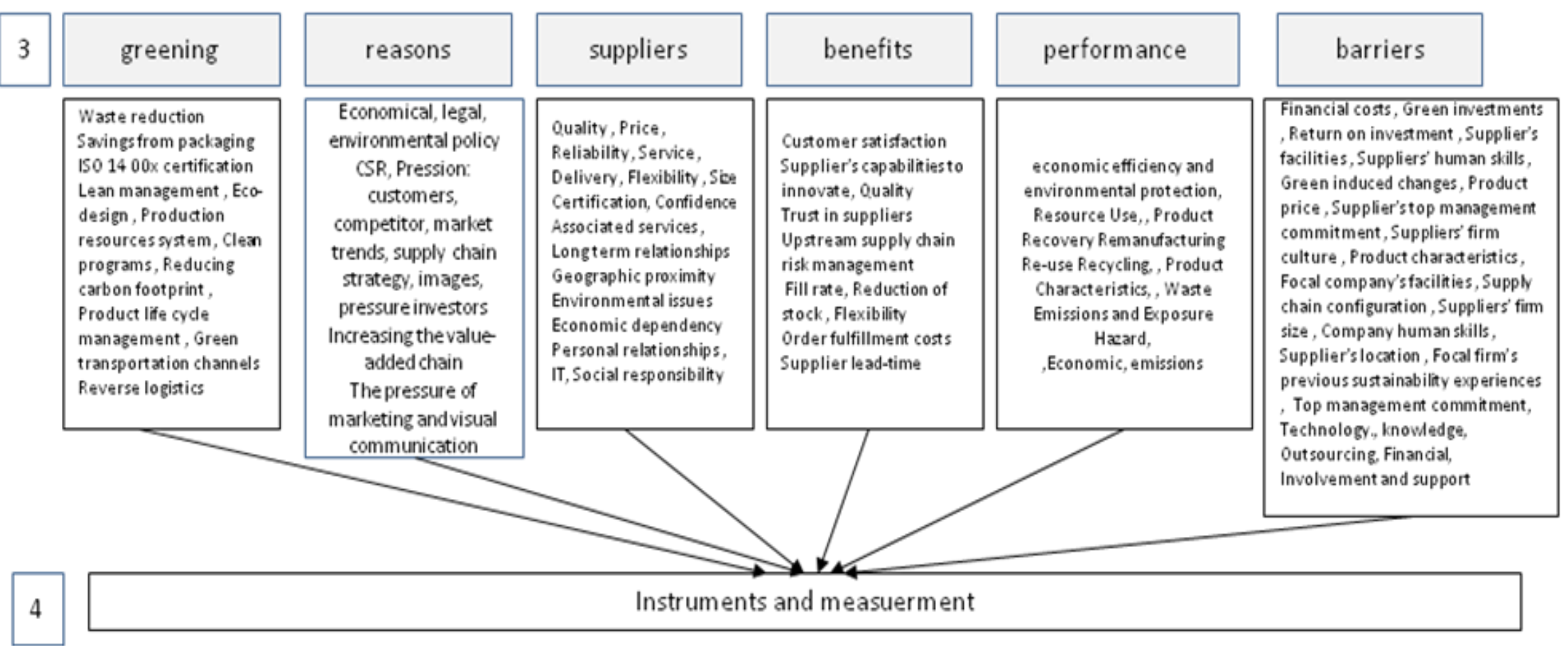

Figure 4. Evaluation elements of a green supply chain. 
The presented tools are the only basis for the selection and collection of the most frequent tools (see Table 1). Keep in mind that depending on the sector activity other tools can be used. Here, macroeconomic elements are often presented, which when using on the level of the chain is not adequate, but can serve as a comparison.

On the basis of such extensive literature studies, one can conclude that there is no clear and definite catalog of measures for a green or sustainable chain, while there is a multitude of instruments, tools, and methods that may mislead and lack comparability for different entities. This means that future research should clearly describe several KPIs (Key Performance Indexes) that would serve to assess a chain in terms of sustainable performance measurement.

\section{Field Analysis-Preparing of the Empirical Research}

The paper was prepared using the method of critical analysis in the literature [110]. On this basis, the criteria catalog for the selection and evaluation of suppliers in the supply chains was selected. The focus has been placed on the sustainable selection criteria presented in the structural modeling approach and application framework in the search for the relationship in the green supply chain and their empirical verification of the model on the research questionnaire basis. The empirical studies were prepared in the form of a questionnaire [111], then a sample of the research was selected and empirical studies were carried out on a selected group of entities. Authors, in the research processes, considered four groups of tools (most often indicated among respondents): KPI (in general, without indicating which elements are included), BSC-Balanced scorecard, Eco effectiveness, and LCA—Life Cycle Assessment. The others appearing in the answers (as an answer: "others", which has been suggested by the respondents) tools, were very rare and not significant in the research.

\section{Results}

\subsection{Data Collection}

The next step of this research was the market analysis. The questionnaire was based on an in-depth analysis of the literature, interviews with experts, and a scientific discussion. It was then possible, while also referring to the formulated hypotheses and identified research areas, to develop the survey questions. The research covered aspects relating to the creation and assessment of green supply chains. This included questions on the use of different criteria for supplier selection (including sustainability), and the use of elements of sustainable development for the creation and evaluation of green supply chains. Answers to the questions were designed in such a way that the respondents answering used the 5 point Likert scale (1-never/very rarely, 5-very often/always).

The survey using a questionnaire was conducted throughout Poland, using the CATI method, in conjunction with an extensive questionnaire and the need to sacrifice more time to fill it in, that interviewers carried out over a three-month period. The research process made it possible to examine 549 organizations operating in Poland in the predefined sectors. The survey was directed at the food industry—conventional, food industry—organic, clothing apparel manufacturing, home appliance manufacturers, sales network of grocery and general merchandise retailer, sales network of home appliances, and sales network of retail-clothing. The number of surveys and queries were addressed to 1709 units, with a confidence level of $99 \%$ and a $2 \%$ error estimation. The questionnaire was completed by 481 companies, about $28 \%$ of those who received it, including 327 large companies (more than 100 employees) and 154 medium-sized companies (from 50 to 99 employees). Those who responded to the questionnaire were middle to senior management including, for example, a supply chain manager, a logistics manager, a head of logistics and supply chain, and a procurement and purchasing manager. The number of investigated objects stemmed from the assumptions of the correct statistical survey. Data collected from the survey were processed and analyzed to provide a basis for making considerations, analysis, drawing conclusions, and formulating recommendations. 


\subsection{Empirical Findings}

The questionnaire included, in addition to questions about the company itself, i.e., its size, business profile, location, certificates held, etc., more than 50 questions about the understanding of the green or sustainable supply chain, the level of their implementation, the tools, and the methods used related to it. The results presented below show the most interesting compounds and the most important elements of the survey on sustainable and green supply chains.

The first analysis carried out was a comparison of the number of enterprises by role in the supply chain (manufacturer, provider, and retailer) and having environmental certificates (ISO 1400x, EMAS or other)—questions 6, 7 in Appendix A. An investigation was carried out into medium-sized and large companies, separately. The results are presented in Figure 5A,B, respectively. Approximately $24 \%$ of all 154 medium-sized companies and $93 \%$ of all 327 companies had a certificate. For medium-sized companies, the highest number of certificates were held by manufacturers, but the highest percentage of certificates were held by retailers (almost $40 \%$ ). In large companies, both manufacturers and retailers were mostly certified (more than $93 \%$ in both groups). The higher the number of certificates in large companies, the higher the visibility and relevance of the tool as a competitive element. Secondly, it is easier for companies to prepare for the certification process and after that they often become a link in the global supply chain. The leader of the supply chain needs to have this type of solution.

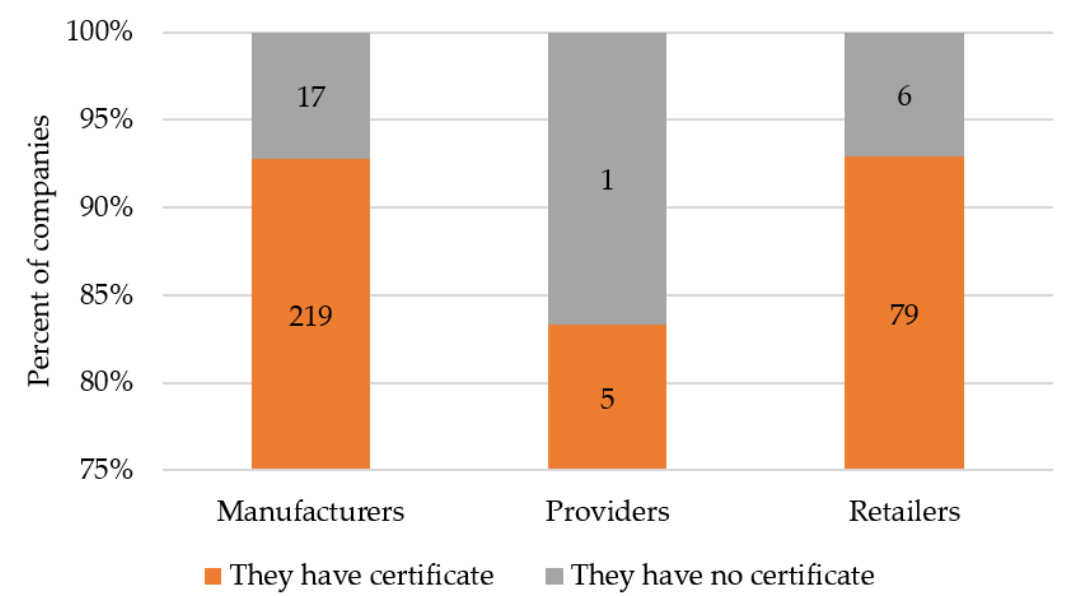

(A)

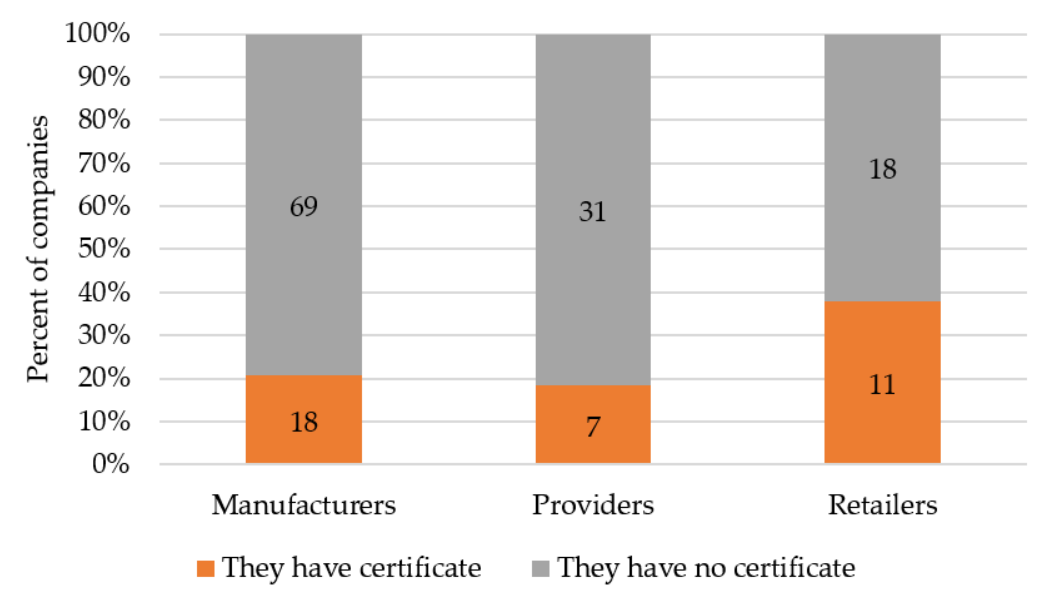

(B)

Figure 5. (A) Number of environmental certificates held by individual groups in the supply chain for medium-sized companies; (B) Number of environmental certificates held by individual groups in the supply chain for large companies. 
Figure 6 presents the number of companies with certifications in comparison to how long they have been implementing the green supply chain/green logistics (environmental aspects), distinguishing between medium-sized and large companies-question 8 in Appendix A. For medium-sized companies, it was observed that the number of certificates increased with the period of implementing the green supply chain in comparison to large companies where the number of certificates was similar for all periods of time. Among the large companies, even those that implemented environmental aspects in a short period of time- $0-2$ years - were mostly certified. Additionally, it is important to note that companies that declared that they had not introduced aspects of the green supply chain also had environmental certifications (10 among medium-sized companies, and 24 among large companies).

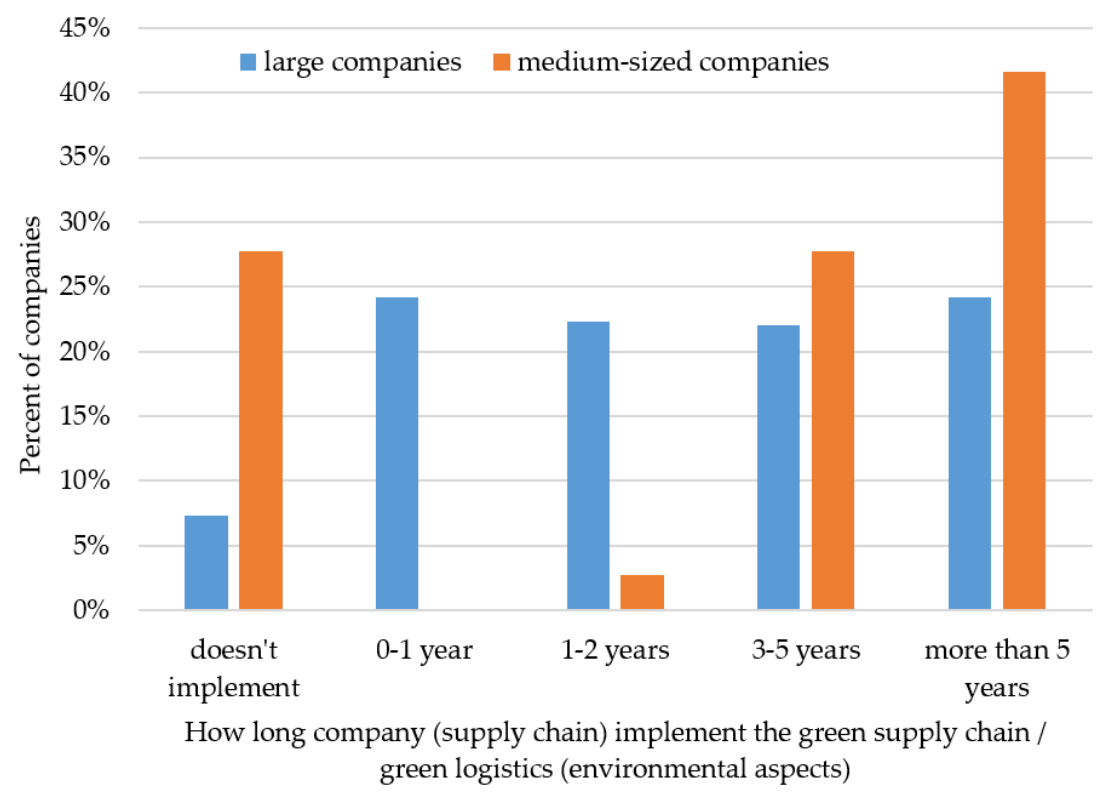

Figure 6. Number of companies with environmental certifications vs. period of implementing of green supply chain.

The answers to the two presented questions presented are related to hypothesis 1 posed by the authors. Environmental certificates are one of the environmental tools used in the supply chain. Their possession is one of the positive elements of creating a green supply chain. The growing number of certificates and its relationship with the implementation of the green chain is undeniable.

A subsequent analysis showed the percentage of companies that analyze the environmental impact of their operations in comparison to companies implementing or planning to implement green and sustainable supply chains (Figure 7A,B)—questions 9, 10 in Appendix A. Comparing the results from the charts, we could see that once again, large companies were more environmentally conscious; more than $80 \%$ of companies analyzed the environmental impact of their operations when compared to medium-sized companies it was between $30-50 \%$. What is interesting, however, that when comparing the companies that are implementing or are about to implement green and sustainable supply chains, the differences were not considerable, especially for large companies (Figure 7B). For medium-sized companies, the percentage was even higher for companies that only intended to implement a sustainable supply chain than those that were already implementing it. 


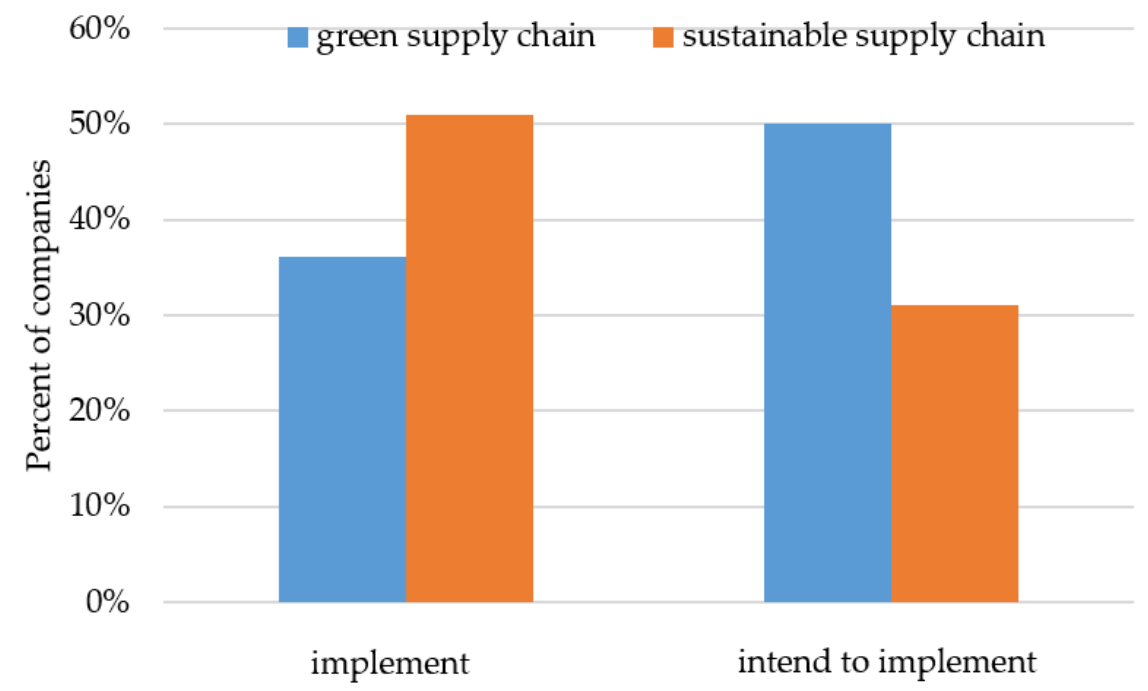

(A)

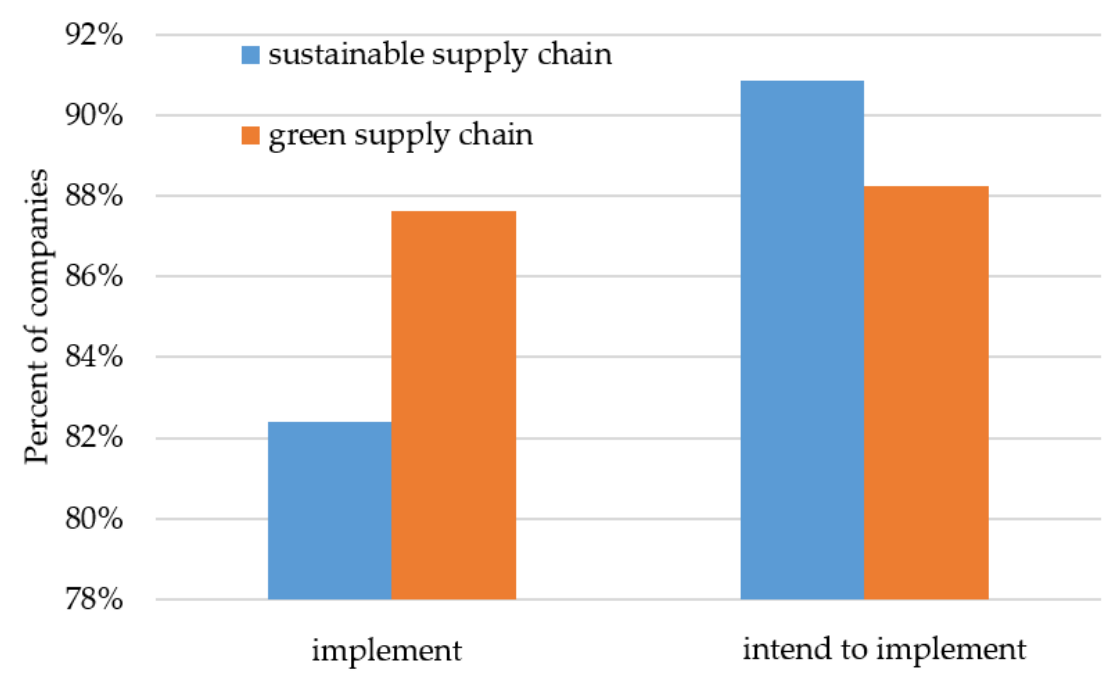

(B)

Figure 7. (A) Number of medium-sized companies that analyze the environmental impact of their operations; (B) Percentage of large companies that analyze the environmental impact of their operations.

The next comparison related to three questions about assessing the efficiency of the supply chain, distinguishing between companies that were implementing or planning to implement green and/or a sustainable supply chain. The respondents answered to the questions listed 1A-1D, 2, 3 in Appendix A.

Figure $8 \mathrm{~A}, \mathrm{~B}$ show the semantic dissimilarities in the efficiency assessment and supply chain performance (questions 1A-1D, 2, 3 Appendix A) in comparison to companies implementing or planning to implement (with a distinction by medium-sized and large enterprises), respectively:

- Green supply chain (Figure 8A),

- Sustainable supply chain (Figure 8B) 


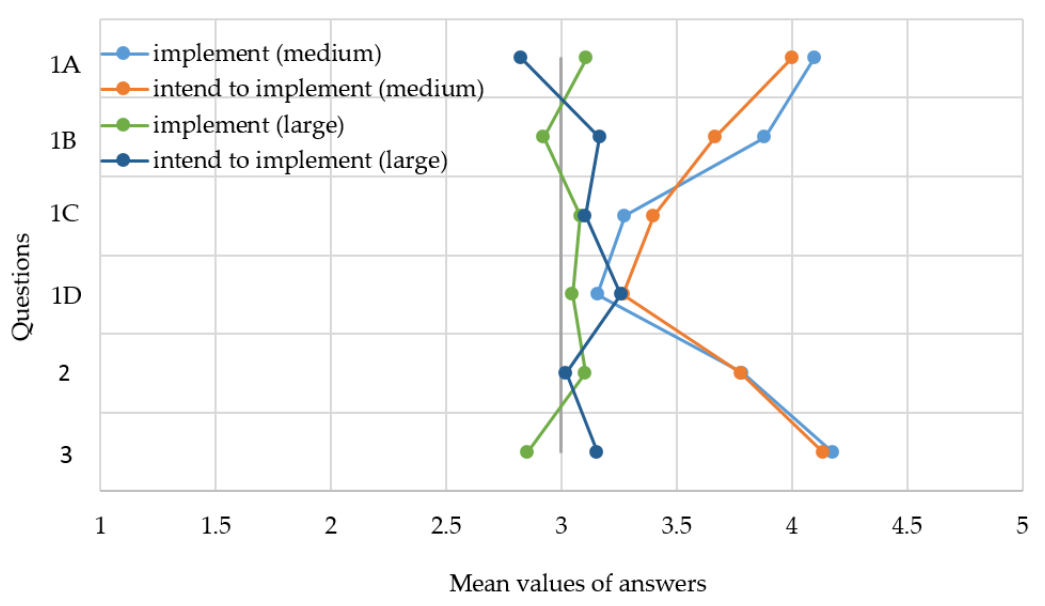

(A)

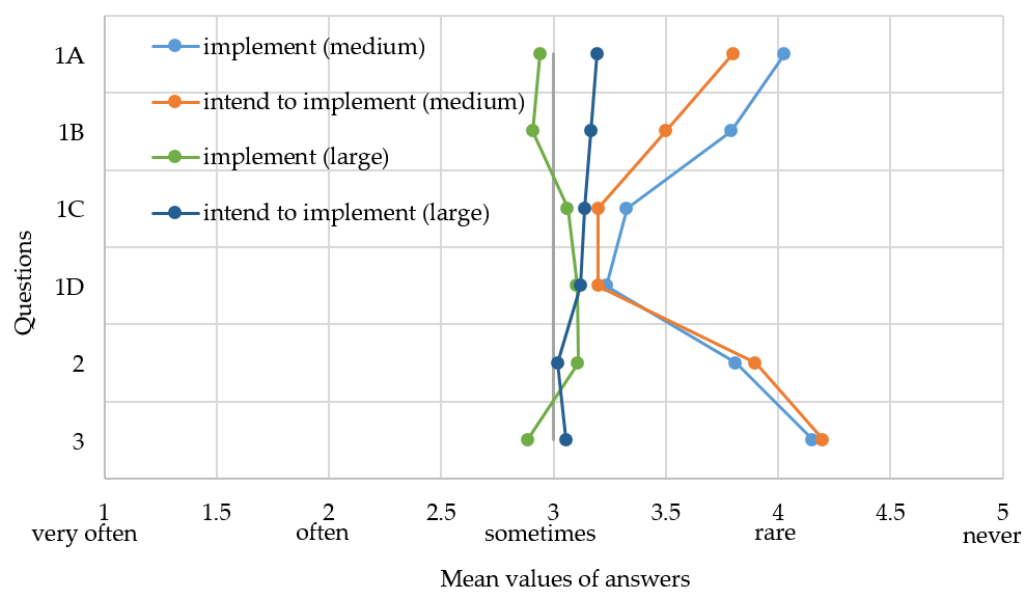

(B)

Figure 8. (A) Differences in the efficiency assessment and supply chain performance in comparison to companies implementing or planning to implement a green supply chain; (B) Differences in the efficiency assessment and supply chain performance in comparison to companies implementing or planning to implement a sustainable supply chain.

From the presented graphs, one can see that much more often (but not so often) were environmental aspects taken into account by managers of large companies. Moreover, it was also evident that the differences between companies which implemented or intended to implement a green supply chain and sustainable supply chain were not big at all.

Figure $8 \mathrm{~A}$ shows the semantic differential in companies implementing or planning to implement a green supply chain, where one can observe that the biggest differences for middle-sized companies were found in questions 1B to 1D. In assessing the efficiency of the supply chain, environmental aspects were taken into account by companies: only in selected areas (1B), only in selected units (1C), and only to evaluate selected processes (1D). Similarly, for large companies, the biggest differences were for questions $1 \mathrm{~A}, 1 \mathrm{~B}, 1 \mathrm{D}$, and 3 . What is important is that companies that declare that they are implementing environmental aspects are doing it more often only in selected units and only to evaluate selected processes. A similar conclusion can be drawn when looking at $1 \mathrm{~B}$ and $1 \mathrm{C}$, where companies who intended to implement a green supply chain more often took into account environmental aspects. It was also significant that managers of large companies were more likely to consider environmental aspects of the whole chain or area level $(1 \mathrm{~A}$ and $1 \mathrm{~B})$ than managers of medium-sized enterprises. Dissimilarities in responses to question 2 on whether dedicated environmental management instruments were used to assess the efficiency and performance of 
the supply chain were not so distinct. For question 3-on whether scientific assessment methods (including ecological efficiency, management methods, modern concepts) were used to assess the efficiency and effectiveness of the supply chain-it was found that greater differences occurred in large companies. Similar conclusions were drawn from Figure $8 \mathrm{~B}$ on the semantic differential in companies implementing or planning to implement a sustainable supply chain. The biggest differences were seen in the answers to questions from $1 \mathrm{~A}$ to $1 \mathrm{C}$ between companies that implemented or intended to implement a sustainable supply chain; however, the differences were still not very big. As in Figure 8A, there were dissimilarities in the responses from medium-sized and large company managers, the largest for questions $1 \mathrm{~A}$ to $1 \mathrm{C}, 2$, and 3 .

To confirm the differences presented by semantic dissimilarities in the efficiency assessment and supply chain performance, an independent analysis was carried out to statistically confirm whether there were any differences to the answers to the questions by the managers of companies that implemented or intended to implement a green supply chain and a sustainable supply chain. By using independent analysis, based on the hypothesis that there were no dependencies between the tested variables and, furthermore, there were no significant dissimilarities between the quantities compared. To show these dependencies the Chi-squared test was applied.

Null hypothesis $H_{0}$ was that there were no differences in the efficiency assessment and supply chain performance (questions 1A-1D, 2, 3) in comparison to companies that implemented or intended to implement a green supply chain and a sustainable supply chain (with a distinction between medium-sized and large companies). All calculations were done in Statistica 10.0 software (Statsoft, Cracow, Poland), and the results are shown in Table 1.

Noticing the values from the $p$-value column from Table 2, it can be seen that the hypothesis $H_{0}$ was rejected. This means that the companies that implemented or intended to implement a green supply chain and a sustainable supply chain had different assessments of the efficiency and supply chain performance.

Table 2. Chi-square and V-Cramer coefficients.

\begin{tabular}{ccccc}
\hline & Companies Implement or Intend to Implement & $\chi^{2}$ & $p$-Value & V Cramer \\
\hline Medium-sized & Green supply chain & 4.5170 & 0.04132 & 0.37412 \\
companies & Sustainable supply chain & 8.3221 & 0.04211 & 0.34216 \\
\hline \multirow{2}{*}{ Large companies } & Green supply chain & 7.2361 & 0.03825 & 0.41732 \\
& Sustainable supply chain & 6.0548 & 0.04413 & 0.38329 \\
\hline
\end{tabular}

In addition, to estimate the strength of this relationship, the V-Cramer coefficient was used. When the value of this coefficient was less than 0.3 it meant that there was a weak relation between the analyzed characteristics. A value between 0.3 and 0.5 meant that there was a moderate relationship, and more than 0.5 meant that there was a strong relationship between these characteristics. From Table 2, one can observe that the V-Cramer coefficient indicates a moderate relation. From this, it can be observed that the largest value of this coefficient was in companies that implemented or intended to implement green logistics for large companies. The presented results of the statistical analysis confirmed the earlier results shown in the graphs that there were differences between those who had already applied the green supply chain and sustainable supply chain principle, and those who intended to use it, but these differences were not very large.

Another analysis (Analysis of variance-ANOVA) was used to examine the significance of differences between entrepreneurs who had implemented and not implemented the green supply chain. Therefore, we used Fisher's law where the ratio of the squares of variances between groups to the squares of variances inside groups was determined according to a certain distribution (Fisher-Snedecor distribution) and it was possible to assess the probability of occurrence of certain $\mathrm{F}$ values.

Analysis of variance (ANOVA) was used to determine if there were differences between implementing or non-implementing the green supply chain in the context of the questions/criterions 4 and 5 (Appendix A). 
The analysis was done by dividing the company into three groups: (1) Manufacturers, (2) Providers, and (3) Retailers with a distinction of medium-sized and large enterprises - Table 3. For criterion 1, the difference between the middle-sized and large companies was significant; in all groups of large companies, there was a difference between companies that declared the implementation or not of a green supply chain regarding taking environmental aspects into account when selecting suppliers/partners (the biggest spread between $F_{0}$ from ANOVA than from Snedecor distribution with small $p$-value at the same time - the bold values in Table 3). The difference was significant for medium-sized companies only for retailers - the bold values in Table 3. However, for criterion 2, when the "green" image was taken into account when selecting a supplier/partner, the difference was with the group of providers from large companies. This means that although entrepreneurs had declared the implementation of a green supply chain, in practice they did not choose suppliers in terms of environmental aspects nor take into account the "green" image.

Summing up the previous results, one can conclude that larger companies had a greater environmental awareness. They mostly had environmental certificates, but they also more often implemented green principles or a sustainable supply chain e.g., a selection of suppliers for environmental aspects. However, research has shown that there were no clear differences between companies that implemented or intended to implement a green or sustainable supply chain. This means that although entrepreneurs declared that they would implement a green supply chain, in practice, they did not pay much more attention to environmental aspects than companies which only just declared the implementation of green chain rules, analyzing in particular the results of the responses of the managers of middle-sized companies, i.e., semantic dissimilarities (Figure 7A,B).

One more important analysis of the survey results was related to the individual performance measurement (questions 11, 12-Appendix A). The results are based on Table 4. It follows that these indicators are known and used as they appear to be the least developed from the balanced scorecard, and most often KPIs (Key Performance Index).

Table 3. Analysis of variance for executed research.

\begin{tabular}{cccccc}
\hline \multicolumn{2}{c}{ Source of Variation } & $\boldsymbol{F}_{\mathbf{0}}$ & $\boldsymbol{p}$-Value & $\boldsymbol{F}_{\mathbf{0}}$ & $p$-Value \\
\hline Companies & & Middle-Sized & \multicolumn{2}{c}{ Large } \\
\hline Criterion 1-one of the selection & Manufacturers & 0.877 & 0.3516 & 4.668 & 0.047 \\
criteria (e.g., supplier, partner) & Providers & 1.043 & 0.3146 & 12.259 & 0.0025 \\
are environmental requirements & Retailers & 13.83 & 0.0009 & 5.277 & 0.039 \\
\hline \multirow{2}{*}{ Criterion 2- "green" image is } & Manufacturers & 2.281 & 0.1346 & 0.212 & 0.645 \\
taken into account & Providers & 1.865 & 0.1828 & 6.670 & 0.018 \\
& Retailers & 0.229 & 0.6357 & 0.569 & 0.452 \\
\hline
\end{tabular}

Table 4. Using the performance measurement-survey analysis.

\begin{tabular}{ccc}
\hline $\boldsymbol{n}=\mathbf{4 8 1}$ & \multicolumn{2}{c}{} \\
\hline & Not Use & Use \\
\hline KPI & 19.67 & 80.33 \\
LCA & 45.72 & 54.28 \\
BSC & 28.23 & 71.77 \\
Eco-effectiveness & 50.09 & 49.91 \\
\hline
\end{tabular}

This was also investigated in companies that indicated that they implemented or used performance indicators in terms of the nature of their activity and in relation to the size of the enterprise, and which factors and which measures were most commonly used (Table 5). 
Table 5. Implementations of LCA—life cycle assessment, BSC—balanced scorecard, KPI—key performance indexes and eco-effectiveness indicators-survey analysis.

\begin{tabular}{|c|c|c|c|c|c|c|c|}
\hline \multicolumn{8}{|c|}{ LCA Implementations } \\
\hline \multirow[b]{2}{*}{ Emp. } & \multicolumn{4}{|c|}{ Industry } & \multicolumn{3}{|c|}{ Retailer/Sales Network } \\
\hline & $\begin{array}{c}\text { Food } \\
\text { Conventional }\end{array}$ & Food Organic & Wearing Apparel & $\begin{array}{c}\text { Home } \\
\text { Appliance }\end{array}$ & $\begin{array}{l}\text { Grocery and } \\
\text { General } \\
\text { Merchandise }\end{array}$ & $\begin{array}{c}\text { Home } \\
\text { Appliance }\end{array}$ & $\begin{array}{l}\text { Wearing } \\
\text { Apparel }\end{array}$ \\
\hline $50-99$ & $12.71 \%$ & $2.68 \%$ & $3.34 \%$ & $2.01 \%$ & $2.34 \%$ & $2.34 \%$ & $1.67 \%$ \\
\hline 100-199 & $4.35 \%$ & $2.34 \%$ & $1.67 \%$ & $1.34 \%$ & $0.33 \%$ & $1.67 \%$ & $1.34 \%$ \\
\hline $200-249$ & $7.36 \%$ & $1.67 \%$ & $1.67 \%$ & $1.34 \%$ & $2.34 \%$ & $0.67 \%$ & $0.67 \%$ \\
\hline $250-499$ & $6.02 \%$ & $1.34 \%$ & $0.33 \%$ & $1.00 \%$ & $0.67 \%$ & $1.67 \%$ & $0.67 \%$ \\
\hline 500-999 & $8.03 \%$ & $2.01 \%$ & $1.67 \%$ & $1.67 \%$ & $2.01 \%$ & $2.01 \%$ & $0.67 \%$ \\
\hline$\geq 1000$ & $5.35 \%$ & $1.67 \%$ & $1.67 \%$ & $1.67 \%$ & $1.34 \%$ & $1.67 \%$ & $1.00 \%$ \\
\hline \multicolumn{8}{|c|}{ BSC Implementation } \\
\hline 50-99 & $26.14 \%$ & $2.28 \%$ & $10.66 \%$ & $2.03 \%$ & $1.78 \%$ & $1.52 \%$ & $1.27 \%$ \\
\hline 100-199 & $3.55 \%$ & $1.52 \%$ & $1.27 \%$ & $0.76 \%$ & $0.25 \%$ & $0.76 \%$ & $0.76 \%$ \\
\hline $200-249$ & $4.82 \%$ & $1.52 \%$ & $1.27 \%$ & $1.02 \%$ & $1.52 \%$ & $0.51 \%$ & $0.25 \%$ \\
\hline $250-499$ & $4.31 \%$ & $0.76 \%$ & $0.25 \%$ & $0.51 \%$ & $0.76 \%$ & $1.52 \%$ & $0.51 \%$ \\
\hline 500-999 & $7.36 \%$ & $1.02 \%$ & $1.52 \%$ & $0.76 \%$ & $1.52 \%$ & $1.02 \%$ & $0.76 \%$ \\
\hline$\geq 1000$ & $4.82 \%$ & $1.52 \%$ & $1.02 \%$ & $1.02 \%$ & $1.27 \%$ & $1.78 \%$ & $0.76 \%$ \\
\hline \multicolumn{8}{|c|}{ KPI Implementation } \\
\hline $50-99$ & $30.39 \%$ & $2.55 \%$ & $19.71 \%$ & $2.92 \%$ & $2.92 \%$ & $2.19 \%$ & $1.46 \%$ \\
\hline 100-199 & $5.84 \%$ & $2.55 \%$ & $1.46 \%$ & $1.09 \%$ & $0.73 \%$ & $1.46 \%$ & $1.09 \%$ \\
\hline $200-249$ & $8.03 \%$ & $1.82 \%$ & $1.82 \%$ & $1.46 \%$ & $2.19 \%$ & $0.73 \%$ & $0.36 \%$ \\
\hline $250-499$ & $6.93 \%$ & $1.82 \%$ & $0.36 \%$ & $0.73 \%$ & $1.09 \%$ & $2.19 \%$ & $0.73 \%$ \\
\hline 500-999 & $9.49 \%$ & $2.19 \%$ & $2.19 \%$ & $1.09 \%$ & $2.19 \%$ & $1.82 \%$ & $1.09 \%$ \\
\hline$\geq 1000$ & $6.20 \%$ & $1.82 \%$ & $1.82 \%$ & $1.46 \%$ & $1.82 \%$ & $1.82 \%$ & $1.09 \%$ \\
\hline \multicolumn{8}{|c|}{ Eco-effectiveness indicators } \\
\hline $50-99$ & $9.12 \%$ & $2.19 \%$ & $2.19 \%$ & $2.55 \%$ & $2.92 \%$ & $1.82 \%$ & $1.46 \%$ \\
\hline 100-199 & $5.11 \%$ & $2.55 \%$ & $2.19 \%$ & $1.09 \%$ & $0.73 \%$ & $1.82 \%$ & $1.46 \%$ \\
\hline $200-249$ & $8.03 \%$ & $2.92 \%$ & $1.82 \%$ & $1.46 \%$ & $2.92 \%$ & $0.36 \%$ & $0.73 \%$ \\
\hline $250-499$ & $6.57 \%$ & $1.46 \%$ & $0.36 \%$ & $0.73 \%$ & $0.73 \%$ & $1.82 \%$ & $0.36 \%$ \\
\hline 500-999 & $9.12 \%$ & $2.19 \%$ & $1.82 \%$ & $1.46 \%$ & $2.19 \%$ & $1.82 \%$ & $0.73 \%$ \\
\hline$\geq 1000$ & $5.47 \%$ & $1.82 \%$ & $1.46 \%$ & $1.09 \%$ & $1.82 \%$ & $1.46 \%$ & $0.36 \%$ \\
\hline
\end{tabular}

From the interpretation of the data contained in Table 5, it can be indicated that hypothesis 2a posed by the authors were verified negatively. Irrespective of the sector, not large, but medium-sized organizations (employing from 50 to 99 employees), most often used environmentally friendly instruments and methods to assess their activities. Although it should be also noted that large organizations which had from 500 to 999 employees were interested in these types of solutions to a large extent. This means that the implementation of modern measurement methods generally did not depend on the size of the organization measured by the number of the employees employed. Hypothesis $2 b$ was also positively verified. The type of organization and the sector in which it operates was not as important in the implementation of environmentally-friendly evaluation tools and the functioning of the supply chain.

In the context of organization division due to the number of employees into medium (those employing up to 99 people) and other (over 100), the results relating to the role they play in creating the green supply chain clearly indicated that large organizations were more often innovators and initiators and leaders (Table 6). On the other hand, middle size organizations tended to continue and adapt solutions that were often passed on by chain leaders. At the same time, organizations that implemented green management tools were more often an adapter and continuator than a leader, or not involved in the implementation of pro-environmental tools. Most organizations that had declared having or implementing pro-environmental tools were somehow involved in the implementation of the green supply chain. Most often, organizations are an imitator, adapter or continuator. In this case, the represented sector as not so important. The connection with the implemented environmental measurement tools had positive relationships. 
Table 6. The role in creating a green supply chain by organizations broken down by the number of employees (in \%).

\begin{tabular}{cccccccc}
\hline & \multicolumn{7}{c}{ General in \% } \\
\hline Emp. & Leader & Initiator & Imitator & Adapting Changes & Continuer & Innovator & Uncommitted \\
\hline $50-99$ & 0.55 & 7.29 & 32.24 & 18.76 & 27.14 & 8.74 & 15.85 \\
$\geq 100$ & 1.46 & 21.13 & 36.25 & 9.11 & 16.94 & 22.40 & 18.40 \\
$50-249$ & 1.09 & 15.85 & 49.00 & 23.32 & 34.06 & 19.31 & 23.13 \\
$\geq 250$ & 0.91 & 12.57 & 19.49 & 4.55 & 10.02 & 11.84 & 11.11 \\
\hline
\end{tabular}

In the context of the classical division of organizations into the middle, that is, those employing up to 249 people and large ones over 250, the results allowed us to draw conclusions indicating that there were more initiators and imitators in the medium-sized group. Furthermore, innovators also constituted a much larger group than in the case of large organizations. This may mean that the size of an organization affects the role that organizations play in creating a green supply chain, but not very large organizations are always the initiators of change. The results presented in Table 6 allow us to verify Hypothesis 3 positively.

\section{Discussion and Conclusions}

At the beginning of the analysis, there were definite green and sustainable supply chains. It seems reasonable to distinguish between these concepts. However, from the construction of an evaluation system, it can generally be noted that both areas were similar and a part of these instruments could be used in both of the supply chains. The visible difference is indicative of greater emphasis placed in the sustainable chain of reverse processes. In the green chain, a greater emphasis will be placed in the processes related to the design planning and organization processes during a product's life, with particular emphasis on the logistics processes (transport, storage, and packaging), and their impact on the environment. The presented considerations should be the beginning of a discussion on the choice of tools for specific industries. For this part, it will be a constructed empirical and survey-based research.

As a result of the analysis and subsequent reflection, this basis will be taken into consideration with selected and presented areas of the research in the area of green supply chains. It will also define the different instruments and elements of the measurements of the chain. The proliferation of a wide range of instruments indicates the need to make a decision and dedicate some tools for specific sectors.

This consideration has its limitations. Based on the literature, the presented basic framework assessment system model of a green supply chain should be the beginning of a discussion on the choice of tools for specific industries. It shows where and which tools can be implemented in the future complexes evaluations model of the green supply chain. Here, we only indicated areas and described a framework for future work and building a mathematical model on the basis of the empirical research. It is generally considered to be a general model, after its verification on the pods of tests, it will reduce the number of facts and indicators so that it can be used for statistical testing. This is a simplified model, actually, as an indication of the relationships and importance of the different criteria. The verification of practical results refers only to three selected sectors, with each of them predisposed to implementing a green or sustainable supply chain. Perhaps the results would be interesting e.g., for the chemical industry, which is assumed to be un-ecological. This situation implies that the results can be generalized to that economic area. The research covered specifically selected sectors and companies, so the results can be interpreted for these organizations. However, the diversity inside these three specific sectors also allows for the identification of the characteristic elements to be taken into account when choosing a supplier. Considerations do not appear different between specific industries, which on one hand, allow us to draw general conclusions, but on the other hand, is a certain restriction. This section will be a part of further research. The presented results indicate that Polish companies are becoming increasingly important components of sustainable development and green supply chains and do not differ from global trends, although it can be pointed out that 
the concepts of GSCM and SSCM are still in the process of the manufacturing and retailing sectors. This is partly due to the lack of knowledge as well as the traditional (economic) approach to supply chain management. An interesting conclusion from the empirical research is the lack of connection between the size of the organization and the implementation of ecological instruments. It may also be associated with the growing awareness of the environmental protection of a medium-sized company. From another point of view, it could be said that large organizations have many more possibilities to implement environmental instruments to evaluate their supply chain and do not do so as they obtain their profit from other areas. It is important to show organizations that a pro-environmental approach provides the chance for every organization in the chain, for each stakeholder, and for the planet.

However, further efforts should be made to ensure that these tools and instruments are more sustainable. The future directions of research may include the development and implementation of environmentally friendly management instruments and creations of the assessment model of a green supply chain. It may also include work on improving and universalization of the current solutions. Practical verification should be extended to other sectors of the economy, especially those that have failed to embrace the green way of doing things. In the areas already examined, organizations should put more of an emphasis on expanding the sphere of knowledge surrounding the green supply chain and the benefits they bring, and that only by acting together within the whole chain can they achieve their sustainability goals.

The presented considerations can be used as a case study referring to the study of the use of performance measurement for other researchers. They can serve as a basis for comparative analyzes. Poland case study can be a contribution and a clue for the organization in the supply chain in this economy to what other tools and instruments can be used to assess the green supply chain, for those who still do not assess their chains in this respect. This may be a hint as to what should be done in this direction.

Acknowledgments: This paper is an part of the science project financed by National Science Centre granted on the basis of decision DEC-2013/09/B/HS4/02707.

Author Contributions: Blanka Tundys wrote the paper, contributed materials, performed the theoretical part and framework model, wrote discussion and limitations. Tomasz Wiśniewski contributed analysis tools, performed the experiments and analyzed the data, wrote discussion and limitations.

Conflicts of Interest: The authors declare no conflict of interest. The founding sponsors had no role in the design of the study; in the collection, analyses, or interpretation of data; in the writing of the manuscript, and in the decision to publish the results.

\section{Appendix}

Questions from the survey that are used in the research of this article are listed below. Answers for questions by key: 1-very often, 2-often, 3-sporadically, 4-rarely, 5-never.

(1) In assessing the efficiency of the supply chain, environmental aspects are taken into account:

(A) At the chain level

(B) Only in selected areas

(C) Only in selected units

(D) Only to evaluate selected processes

(2) Dedicated environmental management instruments are used to assess the efficiency and performance of the supply chain.

(3) Scientific assessment methods (including ecological efficiency, management methods, modern concepts) are used to assess the efficiency and effectiveness of the supply chain.

(4) Is one of the selection criteria (e.g., supplier, partner) an environmental requirement? Please evaluate how often this criterion is used.

(5) How often is the aspect of "green" image taken into account when selecting a supplier/partner? Please assess the grade to be taken into account. 
(6) Does your company have environmental certificates:
(a) ISO 1400x
(b) EMAS
(c) other...
(d) does not have

(7) What is the role of your company in the supply chain:
(a) manufacturer
(b) provider
(c) retailer

(8) How long does your company (supply chain) implements the principles of green supply chain/green logistics (environmental aspects):
(a) less than one year
(b) 1-2 years
(c) 3-5 years
(d) over 5 years
(e) does not implement

(9) If your company analyzes the environmental impact of your operations: yes/no?

(10) Which concept of your company/supply chain implements or intends to implement in the future:
(a) green supply chain
(b) sustainable supply chain

(11) To assess of the green supply chain, are used (yes/no);

1. KPI (in general, without indicating which elements are included),

2. BSC-Balanced scorecard,

3. Eco effectiveness,

4. LCA-Life Cycle Assessment,

5. Others...

(12) What type of business do you represent

1. Industry:

- food-conventional,

- food-organic,

- clothing apparel,

- home appliance.

2. Retailer:

- sales network of grocery and general merchandise,

- sales network of home appliances,

- sales network of retail-clothing.

\section{References}

1. Kassenberg, A.; Karaczun, Z; Owczarek, D. Securing Means of Implementation in Poland; Asia-Europe Foundation (ASEF): Singapore, 2015.

2. Estampe, D.; Lamouri, S.; Paris, J.L.; Brahim-Djelloul, S. A framework for analysing supply chain performance evaluation models. Inter. J. Prod. Econ. 2013, 142, 247-258. [CrossRef] 
3. Zhu, Q.; Sarkis, J.; Lai, K.H. Confirmation of a measurement model for green supply chain management practices implementation. Inter. J. Prod. Econ. 2008, 111, 261-273. [CrossRef]

4. Malviya, R.K.; Kant, R. Green supply chain management (GSCM): A structured literature review and research implications. BIJ 2015, 22, 1360-1394. [CrossRef]

5. Govindan, K.; Soleimani, H. A review of reverse logistics and closed-loop supply chains: A Journal of Cleaner Production focus. J. Clean. Prod. 2017, 142, 371-384. [CrossRef]

6. Van Hoek, R.I. "Measuring the unmeasurable"-Measuring and improving performance in the supply chain. Supply Chain Manag. 1998, 3, 187-192. [CrossRef]

7. Hervani, A.A.; Helms, M.M.; Sarkis, J. Performance measurement for green supply chain management. BIJ 2005, 12, 330-353. [CrossRef]

8. King, A.A.; Lenox, M.J. Lean and green? An empirical examination of the relationship between lean production and environmental performance. Prod. Oper. Manag. 2001, 10, 244-256. [CrossRef]

9. Varsei, M.; Soosay, C.; Fahimnia, B.; Sarkis, J. Framing sustainability performance of supply chains with multidimensional indicators. Supply Chain Manag. 2014, 19, 242-257. [CrossRef]

10. Maestrini, V.; Luzzini, D.; Maccarrone, P.; Caniato, F. Supply chain performance measurement systems: A systematic review and research agenda. Int. J. Prod. Econ. 2017, 183, 299-315. [CrossRef]

11. Centobelli, P.; Cerchione, R.; Esposito, E. Environmental sustainability in the service industry of transportation and logistics service providers: Systematic literature review and research directions. Transp. Res. D 2017, 53, 454-470. [CrossRef]

12. Srivastava, S.K. Green supply-chain management: A state-of-the-art literature review. Int. J. Manag. Rev. 2007, 9, 53-80. [CrossRef]

13. Beamon, B.M. Designing the green supply chain. Logist. Infor. Manag. 1999, 12, 332-342. [CrossRef]

14. Davies, J.; Hochman, S. The greening of the supply chain. Supply Chain Manag. Rev. 2007, 11, $13-14$.

15. Rettab, B.; Ben Brik, A. Green Supply Chain in Duba; Dubai Chamber Centre for Responsible Business: Dubai, UAE, 2008.

16. Zhu, Q.; Sarkis, J. An inter-sectoral comparison of green supply chain management in China: Drivers and practices. J. Clean. Prod. 2006, 14, 472-486. [CrossRef]

17. Gilbert, S. Greening Supply Chain: Enhancing Competitiveness through Green Productivity; Asian Productivity Organization: Tapei, Taiwan, 2001.

18. Hwa, T.J. Green productivity and supply chain management. In Proceedings of the Conference on Enhancing Competitiveness through Green Productivity, Taipei, Taiwan, 25-27 May 2000; Asian Productivity Organization: Tokyo, China, 2000; pp. 25-27.

19. Rao, P.; Holt, D. Do green supply chains lead to competitiveness and economic performance? Int. J. Oper. Prod. Man. 2005, 25, 898-916. [CrossRef]

20. Vachon, S.; Klassen, R.D. Environmental management and manufacturing performance: The role of collaboration in the supply chain. Int. J. Prod. Econ. 2008, 111, 299-315. [CrossRef]

21. Zsidisin, G.A.; Siferd, S.P. Environmental purchasing: A framework for theory development. Eur. J. Purch. Supply Manag. 2001, 7, 61-73. [CrossRef]

22. Skjoett-Larsen, T. Third party logistics-from an interorganizational point of view. Int. J. Phys. Distr. Log. 2000, 30, 112-127. [CrossRef]

23. 13 Beamon, B.M. Sustainability and the future of supply chain management. Oper. Supply Chain Manag. 2008, 1, 4-18.

24. Chiou, T.Y.; Chan, H.K.; Lettice, F.; Chung, S.H. The influence of greening the suppliers and green innovation on environmental performance and competitive advantage in Taiwan. Transp. Res. E Logist. 2011, 47, 822-836. [CrossRef]

25. Centobelli, P.; Cerchione, R.; Esposito, E. Developing the WH2 framework for environmental sustainability in logistics service providers: A taxonomy of green initiatives. J. Clean. Prod. 2017, 165, 1063-1077. [CrossRef]

26. Lintukangas, K.; Kähkönen, A.K.; Ritala, P. Supply risks as drivers of green supply management adoption. J. Clean. Prod. 2016, 112, 1901-1909. [CrossRef]

27. Khaksar, E.; Abbasnejad, T.; Esmaeili, A.; Tamošaitienè, J. The effect of green supply chain management practices on environmental performance and competitive advantage: A case study of the cement industry. Technol. Econ. Dev. Econ. 2016, 22, 293-308. [CrossRef] 
28. Govindan, K.; Kaliyan, M.; Kannan, D.; Haq, A.N. Barriers analysis for green supply chain management implementation in Indian industries using analytic hierarchy process. Int. J. Prod. Econ. 2014, 147, 555-568. [CrossRef]

29. Govindan, K.; Sarkis, J.; Jabbour, C.J.C.; Zhu, Q.; Geng, Y. Eco-efficiency based green supply chain management: Current status and opportunities. Eur. J. Oper. Res. 2014, 233, 293-298. [CrossRef]

30. Mathiyazhagan, K.; Govindan, K.; NoorulHaq, A.; Geng, Y. An ISM approach for the barrier analysis in implementing green supply chain management. J. Clean. Prod. 2013, 47, 283-297. [CrossRef]

31. Muduli, K.; Govindan, K.; Barve, A.; Geng, Y. Barriers to green supply chain management in Indian mining industries: A graph theoretic approach. J. Clean. Prod. 2013, 47, 335-344. [CrossRef]

32. Mudgal, R.K.; Shankar, R.; Talib, P.; Raj, T. Modelling the barriers of green supply chain practices: An Indian perspective. Int. J. Logist. Syst. Manag. 2010, 7, 81-107. [CrossRef]

33. Xia, X.; Govindan, K.; Zhu, Q. Analyzing internal barriers for automotive parts remanufacturers in China using grey-DEMATEL approach. J. Clean. Prod. 2015, 87, 811-825. [CrossRef]

34. Rauer, J.; Kaufmann, L. Mitigating External Barriers to Implementing Green Supply Chain Management: A Grounded Theory Investigation of Green-Tech Companies' Rare Earth Metals Supply Chains. J. Supply Chain Manag. 2015, 51, 65-88. [CrossRef]

35. Perotti, S.; Zorzini, M.; Cagno, E.; Micheli, G.J.L. Green supply chain practices and company performance: The case of 3PLs in Italy. Int. J. Phys. Distrib. Logist. Manag. 2012, 45, 640-672. [CrossRef]

36. Azevedo, S.G.; Carvalho, H.; Machado, V.C. The influence of green practices on supply chain performance: A case study approach. Trans. Res. Part E: Logist. Trans. Rev. 2011, 47, 850-871. [CrossRef]

37. Diabat, A.; Govindan, K. An analysis of the drivers affecting the implementation of green supply chain management. Resour. Conserv. Recycl. 2011, 55, 659-667. [CrossRef]

38. Wang, Z.; Mathiyazhagan, K.; Xu, L.; Diabat, A. A decision making trial and evaluation laboratory approach to analyze the barriers to Green Supply Chain Management adoption in a food packaging company. J. Clean. Prod. 2016, 117, 19-28. [CrossRef]

39. Miranda-Ackerman, M.A.; Azzaro-Pantel, C.; Aguilar-Lasserre, A.A. A green supply chain network design framework for the processed food industry: Application to the orange juice agrofood cluster. Comput. Ind. Eng. 2017, 109, 369-389. [CrossRef]

40. Garg, C.; Sharma, A.; Goyal, G. A hybrid decision model to evaluate critical factors for successful adoption of GSCM practices under fuzzy environment. Uncertain Supply Chain Manag. 2017, 5, 59-70. [CrossRef]

41. Chang, R.D.; Zhang, Y.; Chen, Y.L. The implementation of green supply chain management in chinese food industry: A multi-case study. In Proceedings of 2012 3rd International Asia Conference on Industrial Engineering and Management Innovation (IEMI2012); Dou, R., Ed.; Springer: Berlin/Heidelberg, Germany, 2013; pp. 379-387. [CrossRef]

42. Nema, N.; Soni, S.R.; Talankar, A.; Nougriaya, S. Green Supply Chain Management Practices in Textile and Apparel Industries: Literature Review. Int. J. Eng. Technol. Manag. Res. 2013, 1, 330-336.

43. Zhou, F. Study on the implementation of green supply chain management in textile enterprises. J. Sus. Dev. 2009, 2, 75-79. [CrossRef]

44. Shen, B.; Li, Q.; Dong, C.; Perry, P. Sustainability issues in textile and apparel supply chains. Sustainability 2017, 9, 1592. [CrossRef]

45. Scur, G.; Barbosa, M.E. Green supply chain management practices: Multiple case studies in the Brazilian home appliance industry. J. Clean. Prod. 2017, 141, 1293-1302. [CrossRef]

46. Ai, X.; Xiangpei, H.; Shufeng, G. A three-player game model for the green supply chain in the home appliance industry. In Proceedings of the 8th International Conference on Innovation \& Management, Wuhan, China, 30 November-2 December 2011; pp. 578-583.

47. Vanalle, R.M.; Ganga, G.M.D.; Godinho Filho, M.; Lucato, W.C. Green supply chain management: An investigation of pressures, practices, and performance within the Brazilian automotive supply chain. J. Clean. Prod. 2017, 151, 250-259. [CrossRef]

48. Caniëls, M.C.; Gehrsitz, M.H.; Semeijn, J. Participation of suppliers in greening supply chains: An empirical analysis of German automotive suppliers. J. Purch. Supply Manag. 2013, 19, 134-143. [CrossRef]

49. Sanghavi, P.; Rana, Y.; Shenoy, S.; Yadav, R. A Review on Green Supply Chain Management in Automobile Industry. Int. J. Curr. Eng. Technol. 2015, 5, 3697-3702. 
50. Feng, W.; Sifeng, L.; Haibin, L.; Yanping, L.; Weizhao, L. A Demonstrative Study for Risk Factors of Green Supply Chain Management-with the Automobile Manufacturing Industry of Guangxi as an Example. In Proceedings of the 2nd China Energy Scientist Forum, Xuzhou, China, 18-19 October 2010; pp. 211-217.

51. Zhao, R.; Liu, Y.; Zhang, N.; Huang, T. An Optimization Model for Green Supply Chain Management by Using a Big Data Analytic Approach. J. Clean. Prod. 2016, 142, 1085-1097. [CrossRef]

52. Green, K.W., Jr.; Zelbst, P.J.; Meacham, J.; Bhadauria, V.S. Green supply chain management practices: Impact on performance. Supply Chain Manag. 2012, 17, 290-305. [CrossRef]

53. Sharma, V.; Chandna, P.; Bhardwaj, A. Green supply chain management related performance indicators in agro industry: A review. J. Clean. Prod. 2016, 141, 1195-1208. [CrossRef]

54. Carter, C.R.; Rogers, D.S. A framework of sustainable supply chain management: moving toward new theory. Int. J. Phys. Distr. Logist. 2008, 38, 360-387. [CrossRef]

55. Paksoy, T.; Bektaş, T.; Özceylan, E. Operational and environmental performance measures in a multi-product closed-loop supply chain. Trans. Res. Part E: Logist. Trans. Rev. 2011, 47, 532-546. [CrossRef]

56. Seuring, S.; Müller, M. From a literature review to a conceptual framework for sustainable supply chain management. J. Clean. Prod. 2008, 16, 1699-1710. [CrossRef]

57. Ansari, Z.N.; Kant, R. A state-of-art literature review reflecting 15 years of focus on sustainable supply chain management. J. Clean. Prod. 2017, 142, 2524-2543. [CrossRef]

58. Beske, P.; Seuring, S. Putting sustainability into supply chain management. Supply Chain Manag. 2014, 19, 322-331. [CrossRef]

59. Ahi, P.; Searcy, C. A comparative literature analysis of definitions for green and sustainable supply chain management. J. Clean. Prod. 2013, 52, 329-341. [CrossRef]

60. Carter, C.R.; Easton, L.P. Sustainable supply chain management: Evolution and future directions. Int. J. Phys. Distr. Log. 2011, 41, 46-62. [CrossRef]

61. Rajeev, A.; Pati, R.K.; Padhi, S.S.; Govindan, K. Evolution of sustainability in supply chain management: A literature review. J. Clean. Prod. 2017, 162, 299-314. [CrossRef]

62. Chen, I.J.; Kitsis, A.M. A research framework of sustainable supply chain management: The role of relational capabilities in driving performance. Int. J. Logist. Manag. 2017, 28, 1454-1478. [CrossRef]

63. Dubey, R.; Gunasekaran, A.; Papadopoulos, T.; Childe, S.J.; Shibin, K.T.; Wamba, S.F. Sustainable supply chain management: framework and further research directions. J. Clean. Prod. 2017, 142, 1119-1130. [CrossRef]

64. Bendul, J.C.; Rosca, E.; Pivovarova, D. Sustainable supply chain models for base of the pyramid. J. Clean. Prod. 2017, 162, S107-S120. [CrossRef]

65. Wu, J.Z.; Santoso, C.H.; Roan, J. Key factors for truly sustainable supply chain management: An investigation of the coal industry in Indonesia. Int. J. Logist. Manag. 2017, 28, 1196-1217. [CrossRef]

66. Hong, J.; Zhang, Y.; Ding, M. Sustainable supply chain management practices, supply chain dynamic capabilities, and enterprise performance. J. Clean. Prod. 2017, in press. [CrossRef]

67. Frostenson, M.; Prenkert, F. Sustainable supply chain management when focal firms are complex: A network perspective. J. Clean. Prod. 2015, 107, 85-94. [CrossRef]

68. Song, W.; Ming, X.; Liu, H.C. Identifying critical risk factors of sustainable supply chain management: A rough strength-relation analysis method. J. Clean. Prod. 2017, 143, 100-115. [CrossRef]

69. Gopalakrishnan, K.; Yusuf, Y. Y.; Musa, A.; Abubakar, T.; Ambursa, H.M. Sustainable supply chain management: A case study of British Aerospace (BAe) Systems. Int. J. Prod. Econ. 2012, 140, 193-203. [CrossRef]

70. Chaudhary, T.; Chanda, A. Evaluation and measurement of performance, practice and pressure of green supply chain in Indian manufacturing industries. Uncertain Supply Chain Manag. 2015, 3, 363-374. [CrossRef]

71. Chiarini, A. (Ed.) Sustainable Operations Management: Advances in Strategy and Methodology; Springer: Cham, Switzerland, 2015.

72. Dekker, R.; Fleischmann, M.; Inderfurth, K.; van Wassenhove, L.N. (Eds.) Reverse Logistics: Quantitative Models for Closed-Loop Supply Chains; Springer Science \& Business Media: Berlin/Heidelberg, Germany, 2013.

73. Faruk, A.C.; Lamming, R.C.; Cousins, P.D.; Bowen, F.E. Analyzing, mapping, and managing environmental impacts along supply chains. J. Ind. Ecol. 2001, 5, 13-36. [CrossRef]

74. Ahi, P.; Searcy, C. An analysis of metrics used to measure performance in green and sustainable supply chains. J. Clean. Prod. 2015, 86, 360-377. [CrossRef] 
75. Rebitzer, G. Integrating life cycle costing and life cycle assessment for managing costs and environmental impacts in supply chains. In Cost Management in Supply Chains; Physica: Berlin/Heidelberg, Germany, 2002; pp. 127-146.

76. Schrödl, H.; Simkin, P. A SCOR perspective on Green SCM. In Proceedings of CONF-IRM, Natal, Brazil, 22-24 May 2013; p. 7.

77. Bai, C.; Sarkis, J.; Wei, X.; Koh, L. Evaluating ecological sustainable performance measures for supply chain management. Supply Chain Manag. Int. J. 2012, 17, 78-92. [CrossRef]

78. Lee, J.; Kim, I.; Kwon, E.; Hur, T. Comparison of simplified LCA and matrix methods in identifying the environmental aspects of products. In Proceedings of the 2003 EcoDesign 3rd International Symposium on Environmentally Conscious Design and Inverse Manufacturing, Tokyo, Japan, 8-11 December 2003; pp. 682-686.

79. Moriguchi, Y.; Hashimoto, S. Material flow analysis and waste management. In Taking Stock of Industrial Ecology; Springer: Cham, Switzerland, 2016; pp. 247-262.

80. Pusporini, P.; Abhary, K.; Luong, L. Integrating environmental requirements into quality function deployment for designing eco-friendly product. Int. J. Mater. Mech. Manuf. 2013, 1, 80-84. [CrossRef]

81. Reefke, H.; Trocchi, M. Balanced scorecard for sustainable supply chains: Design and development guidelines. Int.J. Prod. Perfor. Manag. 2013, 62, 805-826. [CrossRef]

82. Sundarakani, B.; De Souza, R.; Goh, M.; Wagner, S.M.; Manikandan, S. Modeling carbon footprints across the supply chain. Int. J. Prod. Econ. 2010, 128, 43-50. [CrossRef]

83. Gurel, O.; Acar, A.Z.; Onden, I.; Gumus, I. Determinants of the green supplier selection. Procedia-Soc. Behav. Sci. 2015, 181, 131-139. [CrossRef]

84. Tyagi, M.; Kumar, P.; Kumar, D. Parametric selection of alternatives to improve performance of green supply chain management system. Procedia-Soc. Behav. Sci. 2015, 189, 449-457. [CrossRef]

85. Galankashi, M.R.; Chegeni, A.; Soleimanynanadegany, A.; Memari, A.; Anjomshoae, A.; Helmi, S.A.; Dargi, A. Prioritizing green supplier selection criteria using fuzzy analytical network process. Procedia CIRP 2015, 26, 689-694. [CrossRef]

86. Chen, C.C.; Shih, H.S.; Shyur, H.J.; Wu, K.S. A business strategy selection of green supply chain management via an analytic network process. Comput. Math. Appl. 2012, 64, 2544-2557. [CrossRef]

87. Srivastava, S.K. Green supply-chain management: A state-of-the-art literature review. Int. J. Manag. Rev. 2007, 9, 53-80. [CrossRef]

88. Sarkis, J.; Zhu, Q.; Lai, K.H. An organizational theoretic review of green supply chain management literature. Int. J. Prod. Econ. 2011, 130, 1-15. [CrossRef]

89. Belvedere, V.; Grando, A. Sustainable Operations and Supply Chain Management; John Wiley \& Sons: Pondicherry, India, 2017.

90. Grzybowska, K. Sustainability in the supply chain: Analysing the enablers. In Environmental Issues in Supply Chain Management; Springer: Berlin/Heidelberg, Germany; pp. 25-40.

91. Galve, J.E.; Elduque, D.; Pina, C.; Javierre, C. Sustainable supply chain management: The influence of disposal scenarios on the environmental impact of a $2400 \mathrm{~L}$ waste container. Sustainability 2016, 8, 564. [CrossRef]

92. Grant, D.B.; Wong, C.Y.; Trautrims, A. Sustainable Logistics and Supply Chain Management: Principles and Practices for Sustainable Operations and Management; Kogan Page Publishers: London, UK, 2017.

93. Walton, S.V.; Handfield, R.B.; Melnyk, S.A. The green supply chain: Integrating suppliers into environmental management processes. J. Supply Chain Manag. 1998, 34, 2-11. [CrossRef]

94. Sisco, C.; Chorn, B.; Pruzan-Jorgensen, P.M. Supply Chain Sustainability: A Practical Guide for Continuous Improvement; United Nations Global Compact, 2011; Available online: https:/ / www.bsr.org/reports /BSR_ UNGC_SupplyChainReport.pdf.

95. EU-Regulations. Available online: http:/ / eur-lex.europa.eu/homepage.html (accessed on 25 November 2017).

96. Horbach, J.; Rammer, C.; Rennings, K. Determinants of eco-innovations by type of environmental impact-The role of regulatory push/pull, technology push and market pull. Eco. Econ. 2012, 78, 112-122. [CrossRef]

97. Kemp, R.; Pearson, P. Final Report MEI Project about Measuring Eco-Innovation; UM Merit: Maastricht, The Netherlands, 2007; p. 10. 
98. El Saadany, A.M.A.; Jaber, M.Y.; Bonney, M. Environmental performance measures for supply chains. Manag. Res. Rev. 2011, 34, 1202-1221. [CrossRef]

99. Kafa, N.; Hani, Y.; El Mhamedi, A. Sustainability performance measurement for green supply chain management. IFAC Proc. Volumes 2013, 46, 71-78. [CrossRef]

100. Acquaye, A.; Ibn-Mohammed, T.; Genovese, A.; Afrifa, G.A.; Yamoah, F.A.; Oppon, E. A Quantitative Model for Environmentally Sustainable Supply Chain Performance Measurement. Eur. J. Oper. Res. 2017, in press. [CrossRef]

101. Mishra, D.; Gunasekaran, A.; Papadopoulos, T.; Hazen, B. Green supply chain performance measures: A review and bibliometric analysis. Sus. Prod. Consum 2017, 10, 85-99. [CrossRef]

102. Balfaqih, H.; Nopiah, Z.M.; Saibani, N.; Al-Nory, M.T. Review of supply chain performance measurement systems: 1998-2015. Comput. Ind. 2016, 82, 135-150. [CrossRef]

103. Lima-Junior, F.R.; Carpinetti, L.C.R. Quantitative models for supply chain performance evaluation: A literature review. Comput. Ind. Eng. 2017, 113, 333-346. [CrossRef]

104. Zhu, Q.; Sarkis, J.; Lai, K. Examining the effects of green supply chain management practices and their mediations on performance improvements. Int. J. Prod. Res. 2012, 50, 1377-1394. [CrossRef]

105. Golicic, S.L.; Smith, C.D. A Meta-Analysis of Environmentally Sustainable Supply Chain Management Practices and Firm Performance. J. Supply China Manag. 2013, 49, 78-95. [CrossRef]

106. Laari, S.; Töyli, J.; Solakivi, T.; Ojala, L. Firm performance and customer-driven green supply chain management. J. Clean. Prod. 2016, 112, 1960-1970. [CrossRef]

107. Dubey, R.; Gunasekaran, A.; Chakrabarty, A. World-class sustainable manufacturing: Framework and a performance measurement system. Int. J. Prod. Res. 2015, 53, 5207-5223. [CrossRef]

108. Schrettle, S.; Hinz, A.; Scherrer-Rathje, M.; Friedli, T. Turning sustainability into action: Explaining firms' sustainability efforts and their impact on firm performance. Int. J. Prod. Econ. 2014, 147, 73-84. [CrossRef]

109. Das, D. Development and validation of a scale for measuring Sustainable Supply Chain Management practices and performance. J. Clean. Prod. 2017, 164, 1344-1362. [CrossRef]

110. Cottrell, S. Critical Thinking Skills: Developing Effective Analysis and Argument; Palgrave Macmillan: Basingstoke, UK, 2011.

111. Lydeard, S. The questionnaire as a research tool. Fam. Pract. 1991, 8, 84-91. [CrossRef] [PubMed] 